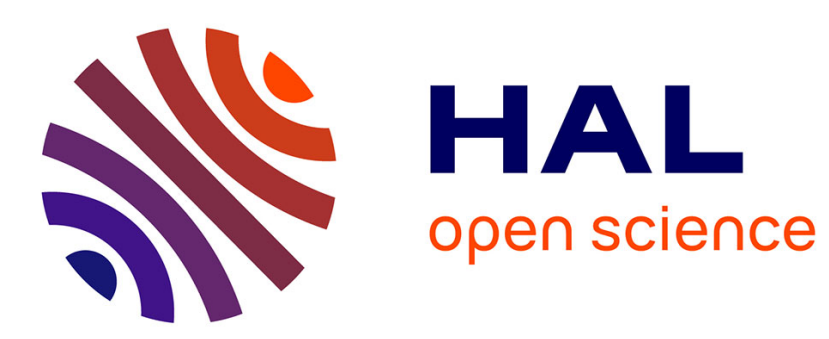

\title{
Gender Discrimination under EU and ECHR Law : Never Shall the Twain Meet?
}

Samantha Besson

\section{To cite this version:}

Samantha Besson. Gender Discrimination under EU and ECHR Law: Never Shall the Twain Meet?. Human Rights Law Review, 2008, 8 (4), pp.647-682. 10.1093/hrlr/ngn023 . hal-02516249

\author{
HAL Id: hal-02516249 \\ https://hal.science/hal-02516249
}

Submitted on 11 May 2020

HAL is a multi-disciplinary open access archive for the deposit and dissemination of scientific research documents, whether they are published or not. The documents may come from teaching and research institutions in France or abroad, or from public or private research centers.
L'archive ouverte pluridisciplinaire HAL, est destinée au dépôt et à la diffusion de documents scientifiques de niveau recherche, publiés ou non, émanant des établissements d'enseignement et de recherche français ou étrangers, des laboratoires publics ou privés. 
Human Rights Law Review 8:4 $\mathcal{O}$ The Author [2008]. Published by Oxford University Press. All rights reserved. For Permissions, please email: journals.permissions@oxfordjournals.org doi:10.1093/hrlr/ngn023 Advance Access publication 21 October 2008

\title{
Gender Discrimination under EU and ECHR Law: Never Shall the Twain Meet?
}

\author{
Samantha Besson*
}

\begin{abstract}
Gender discrimination is addressed differently under Article 14 ECHR and EU primary and secondary legal provisions. This is no wonder, since the role and scope of non-discrimination law in both legal orders are not the same, and since the scope of jurisdiction of the European Court of Human Rights and the European Court of Justice applying those provisions differ drastically as well. While this observation is not new, the potential discrepancy between the two non-discrimination regimes and the two Court's case law constitutes an increasing concern for national authorities and individuals in the 27 European Union (EU) Member States. As a result, gender discrimination is one of the many facets of the current human rights competition raging between the two European organisations, but also of the recent judicial attempts at minimising potential conflicts through mutual borrowings. The present article starts by identifying and comparing the role and scope, as well as the various material and procedural constitutive elements of the two regimes of non-discrimination on grounds of gender. The author argues for a greater systematisation of the two regimes before fruitful borrowings can take place or else the latter will jeopardise the overall coherence of the law on gender discrimination and the specificities in each of the two regimes. The article also argues that EU accession to the ECHR will not, as it is often argued, threaten the specificity of EU antidiscrimination law, but on the contrary enhance the complementarity between EU social law and European human rights law more generally.
\end{abstract}

*Professor of Public International Law and European Law and Co-Director of the European Law Institute, University of Fribourg, Switzerland (samantha.besson@unifr.ch). The piece is the outcome of a comparative constitutional law class I co-taught on Anti-discrimination Law in Europe and the United States in May 2007 at the University of Fribourg. I would like to thank two anonymous referees for their detailed comments and suggestions. Special thanks are also due to Ms Marynelle Debétaz for her assistance with the formal layout of the article. 


\section{Introduction}

Ever since the European Union (EU) started developing fundamental rights guarantees and protection mechanisms, ${ }^{1}$ the relationship between the latter and the Council of Europe's own guarantees in the European Convention of Human Rights (ECHR) has become an increasing concern in the European construction. The recent creation of the EU Fundamental Rights Agency has spurred the controversy even further by threatening the delicate post-war division of labour between the two regional organisations. ${ }^{2}$

The conditions in which European human rights guarantees compete and may conflict are well-known. ${ }^{3}$ It is not only when both the ECHR and EU law apply in a given EU Member State, but also when ECHR rights apply in EU law as (indirect) source of EU fundamental rights, that the question of the coherence of the human rights requirements made by both legal orders arises. The requirements may differ per se, but will in any case often be interpreted differently by the two European courts in charge of their implementation: the European Court of Human Rights (ECtHR) and the European Court of Justice (ECJ). The non-discrimination principle is no exception in this respect. Both EU law and the ECHR now entail a guarantee of the principle of non-discrimination qua human right ${ }^{4}$ and both European Courts have developed an important practice relative to those guarantees. This is also the case

1 See, for example, Case 11/70, Internationale Handelsgesellschaft mbH v Einfuhr- und Vorratsstelle für Getreide und Futtermittel [1970] ECR 1125; Case 5/88, Hubert Wachauf v Bundesamt für Ernährung und Forstwirtschaft [1989] ECR 2609; Case 36-75, Roland Rutili v Ministre de l'intérieur [1975] ECR 1219; Case C-112/00, Eugen Schmidberger, Internationale Transporte und Planzüge v Republik Österreich [2003] ECR I-5659: Case C-36/02, Omega Spielhallen- und Automatenaufstellungs-GmbH v Oberbürgermeisterin der Bundesstadt Bonn [2004] ECR I-9609.

2 See, for example, Omarjee, Robin-Olivier and Sinopoli, 'Conseil de l'Europe - CEDH - La légende de Romulus et Remus Renouvelée: La Lutte de l'Union Européenne et du Conseil de l'Europe pour les Droits Fondamentaux', (2002) Petites Affiches 12. See also, Junker, 'Conseil de l'Europe - Union Européenne: "Une Même Ambition pour le Continent Européen": 11 April 2006, available at: http://assembly.coe.int/Sessions/2006/speeches/ 20060411 rapport.JCJunckerFR.pdf [last accessed 19 June 2008].

3 See, for example, Coppel and O'Neill, 'The European Court of Justice: Taking Rights Seriously', (1992) 12 Legal Studies 227; Alston and Weiler, An "Ever Closer Union" in Need of a Human Rights Policy: The European Union and Human Rights', in Alston, Bustelo and Heenan (eds), The EU and Human Rights (Oxford: Oxford University Press, 1999); von Bogdandy, 'The EU as a Human Rights Organization? Human Rights and the Core of the EU', (2000) 37 Common Market Law Review 1307; Jacobs, 'Human Rights in the EU: The Role of the Court of Justice', (2001) 26 European Law Review 331; and Besson, "The European Union and Human Rights: Towards a Post-National Human Rights Institution?', (2006) 6 Human Rights Law Review 323.

4 See McCrudden and Kountouros. 'Human Rights and European Equality Law', Oxford Legal Studies Research Paper No. 8/2006. available at: http://papers.ssrn.com/sol3/cfdev/ AbsByAuth.cfm?perid=158149 [last accessed 19 June 2008]. See also, Loenen. 'Rethinking Sex Equality as a Human Right', (1994) 12 Netherlands Quarterly of Human Rights 253; Darmon and Huglo, 'L'Égalité de Traitement Entre les Hommes et Les Femmes dans la Jurisprudence de la Cour de Justice des Communautés Européennes: Un Univers en Expansion', (1992) 28 Revue Trimestrielle de Droit Européen 1. 
with respect to gender discrimination. ${ }^{5}$ The difficulty arises from the discrepancy between the two regimes of non-discrimination, both in their fundamental role and aims and in their judicial interpretation. This constitutes a problem mostly for individuals who can receive contradictory judgments from both Courts ${ }^{6}$ and for national authorities and courts that are submitted to contradictory requirements or to the same requirements albeit interpreted differently by both Courts, but also increasingly for the ECJ and the ECtHR when they have regard for each other's law.

Of course, both European legal orders have recently found ways to prevent human rights conflicts. A comparative dialogue was launched between the two courts. ${ }^{7}$ The ECtHR has stated that it would in principle presume EU law to be providing a level of protection equivalent to that of the $\mathrm{ECHR}^{8}$ and it often borrows definitions from the ECJ's case law. ${ }^{9}$ Similarly, the ECJ has shown willingness to abide by the ECtHR's interpretation of the ECHR although the EU has not ratified the Convention ${ }^{10}$ and the EU Charter of Fundamental Rights foresees that its guarantees ought to be interpreted in conformity with the corresponding guarantees of the ECHR (Article 52(3)). ${ }^{11}$ Signs of dialogue

5 See the excellent comparison of both regimes of anti-discrimination law in Martin, Egalité et Non-discrimination dans la Jurisprudence Communautaire - Etude Critique à la Lumière d'une Approche Comparatiste (Bruxelles: Bruylant, 2006). See also, De Schutter, The Prohibition of Discrimination under European Human Rights Law - Relevance for EU Racial and Employment Equality Directives, (Bruxelles: Commission Européenne, 2005).

6 Compare Case C-206/91, Ettien Koua Poirrez v Caisse D'allocations Familiales de la Région Parisienne, Substituée par la Caisse Dallocations Familiales de la Seine-Saint-Denis [1992] ECR I-6685 and Koua Poirrez v France 2003-X; (2005) 40 EHRR 2. See Callewart. 'Paris, Luxembourg, Strasbourg: Trois Juges, Une Discrimination - L'interaction Entre les Ordres Juridiques National, Communautaire et Conventionnel à l'Épreuve de la Pratique (En Marge de l'Arrêt Koua Poirrez)', (2005) Revue Trimestrielle des Droits de l'Homme 999; and Douglas-Scott, A Tale of Two Courts: Luxembourg. Strasbourg and the growing European Human Rights Acquis,' (2006) 43/3 Common Market Law Review 629.

7 See, for example, Douglas-Scott, supra n. 6; Scheeck, "The Relationship between the European Courts and Integration through Human Rights', (2005) 65 Zeitschrift für ausländisches öffentliches Recht und Völkerrecht 837; Simon, 'Des Influences Réciproques Entre CJCE et CEDH: "Je T'Aime. Moi non Plus"?', (2001) Pouvoirs 31; and Nicoll. 'Lessons from Luxembourg: Federalisation and the Court of Human Rights', (2001) 26 European Law Review 7.

8 See Bosphorus Hava Yollari Turizm Ve Ticaret Anonim Sirketi v Ireland (2006) 42 EHRR 1. See comments by Constantinesco, 'C'est Comme si C'était Fait? (Observations à Propos de l'Arrèt de la Cour Européenne des Droits de l'Homme (Grande Chambre), Bosphorus Airlines, du 30 Juin 2005)', (2006) 42 Cahiers de Droit Européen 363; Costello, 'The Bosphorus Ruling of the European Court of Human Rights: Fundamental Rights and Blurred Boundaries in Europe', (2006) 6 Human Rights Law Review 87; and Benoit-Rohmer, 'À Propos de l'Arrêt Bosphorus Air Lines du 30 Juin 2005: l'Adhésion Contrainte de l'Union à la Convention', (2005) 64 Revue Trimestrielle des Droits de l'Homme 827.

9 See, for example, Aristimuno Mendizabal v France (App no 51431/99) (2006) ECHR 34 at para. 69.

10 See, for example. Case C-229/05-P, Osman Öcalan, on behalf of the Kurdistan Workers' Party (PKK) and Serif Vanly, on behalf of the Kurdistan National Congress (KNK) $\vee$ Council of the European Union [2007] ECR I-439.

11 See, for example, Eeckhout, "The EU Charter of Fundamental Rights and the Federal Question', (2002) 39 Common Market Law Review 945; and Lenaerts and De Smijter, "The Charter and the Role of the European Courts', (2001) 8 Maastricht Journal of European Law 49. 
can also be observed in the context of gender discrimination, where both Courts have started to borrow from each other's case law, ${ }^{12}$ albeit very unsystematically and without theorising those borrowings at all. ${ }^{13}$

Whether this constructive dialogue should be encouraged in the long run will be taken for granted in this article. ${ }^{14}$ It is its feasibility, rather, that will be of concern. Both the Convention-compliant interpretation of Charter rights and the ECtHR's equivalence test assume that human rights can be identified, pigeonholed and matched with each other very easily. Human rights practice shows, however, that the same rights are never guaranteed quite in the same way and that the nature and scope of the jurisdiction of the Courts in charge matters a lot when interpreting them. Thus, even though gender discrimination is prohibited per se under both legal orders, its guarantees and their constitutive material and procedural elements vary to such an extent that it is often difficult to compare them efficiently and thus to interpret them in mutually compliant ways. If such a comparison is to be made possible at all and interpretive convergence is to be furthered, the constitutive elements of both regimes first need to be identified and this is the present article's primary aim. Once this has been done, the next question to address is the possibility of promoting their mutual influence without thereby threatening the overall coherence of the two legal regimes of non-discrimination. Accordingly, the article's argument will be three-pronged. After a section on the principle of nondiscrimination in general and its guarantees in the two European legal orders, a second section identifies and compares the prohibitions of genderbased discrimination and their constitutive elements. The final section ventures two proposals for reform.

From a methodological perspective, comparing national constitutional guarantees is not easy. This has to do with the difficult questions of legitimacy and sovereignty comparative law raises, but also with the greater diversity of regimes one encounters in public law than in private law. Comparing the constitutional guarantees ${ }^{15}$ of two international organisations and/or courts is even more problematic, not the least because of the importance of national

12 Compare, for example, Hoogendijk v Netherlands (2005) 40 EHRR SE22 with Case C-343/92, Roks and others $v$ Bestuur van de Bedrijfsvereniging voor de Gezondheid, Geestelijke en Maatschappelijke Belangen and others [1994] ECR I-571 or Stec and others v United Kingdom (2005) 41 EHRR SE18 with Case C-196/98, Regina Virginia Hepple and others v Adjudication Officer [2000] ECR I-3701.

13 See Lernould, 'Egalité Entre les Sexes et Protection Sociale: La Cour Européenne des Droits de I'Homme Sous Influence Commmunautaire', (2006) 8-9 Revue de Jurisprudence Sociale 21; and Martin, 'Strasbourg, Luxembourg et la Discrimination: Influences Croisées ou Jurisprudences sous Influence? (2007) 69 Revue Trimestrielle des Droits de l'Homme 107 at 120, 132-4.

14 See for such an argument, Douglas-Scott, supra n. 6; Scheeck, supra n. 7; Besson, 'From European Integration to European Integrity. Should European law speak with just one voice?', (2004) 10 European Law Journal 257.

15 On post-national constitutionalisation, see, for example, De Wet, "The International Constitutional Order', (2006) 55 International and Comparative Law Quarterly 51. 
law in their conception and implementation. And this even more so since one of them, the EU, is a supranational entity whose legal order is autonomous and binds national law with absolute primacy and direct effect, whereas the other legal order, that of the ECHR, is of inter-governmental nature and follows general international law rules pertaining to the validity, primacy and effect of its norms on national law. ${ }^{16}$ Further, while the ECHR is exclusively a human rights instrument and the ECtHR a specialised human rights court, EU law includes fundamental rights in a broader material legal order and the ECJ is vested with a generalist jurisdiction over EU law. Finally, while the nondiscrimination principle, and especially that of gender discrimination, lies at the core of the EU legal order, the ECHR only protects against gender discrimination as one among many grounds of discrimination. Both orders have in common, however, that they have put in place two of the most incisive regional international courts and that those courts' case law have gradually constituted those two orders in more than 50 years. As such, these two bodies of international case law have a lot in common structurally. Moreover, there is an overlap in the jurisdiction of both their courts since the $27 \mathrm{EU}$ Member States are among the 47 Contracting Parties of the ECHR, thus providing a common public law background to the constitutional comparative exercise. Finally, the recent dialogue launched between the two Courts is the expression of a conscious rapprochement between both sets of European guarantees that has been at work for a long time, thus alleviating some of the legitimacy concerns presented here.

In this article, both legal orders are compared directly and in an integrated fashion rather than presented in turn and then compared. Surprisingly, both Courts have generally avoided theorising and systematizing their respective anti-discrimination regimes, thus rendering this integrated comparison difficult. A choice of constitutive elements from both or either regimes had to be made therefore in order to assess their treatment by both legal orders. Interestingly, the two Courts do not only borrow from each others' case law, but also borrow, sometimes very discretely and generally unsystematically, from other legal orders and in particular from the US Supreme Court's case law on discrimination. ${ }^{17}$ This comparison within the comparison is therefore also highlighted in the article. The object of comparison consists mostly of the

16 On distinct legal orders within the international legal order lato sensu and their relationships, see Besson, 'The Sources of International Law', in Besson and Tasioulas (eds), The Philosophy of International Law (Oxford: Oxford University Press, 2009 forthcoming); and Simma and Pulkowski, 'Of Planets and the Universe: Self-contained Regimes in International Law', (2006) 17 European Journal of International Law 483.

17 Compare, for example, Case 96/80, J.P. Jenkins v Kingsgate (Clothing Productions) Ltd [1981] ECR 911 with Dothard v Rawlinson 433 US 321, 97 S Ct 2720 (1977). See, for example, Flauss, 'La Présence de la Jurisprudence de la Cour Suprême des Etats-Unis d'Amérique dans le Contentieux Européen des Droits de l'Homme', (2005) Revue Trimestrielle des Droits de l'Homme 313; and Martin, supra n. 5 at 493-9. 
two Courts' case law on their respective guarantees of the non-discrimination principle. ${ }^{18}$ Since gender discrimination is regulated by an important amount of primary and secondary norms in EU law, however, anti-discrimination legislation also needs to be included in the comparative material.

\section{The Principle of Non-discrimination in General}

To understand how gender discrimination is regulated under EU and ECHR law, it is important to start by examining the principle of non-discrimination in general in both legal orders. ${ }^{19}$ That principle ought to be distinguished from the principle of equality, before its definition and role can be assessed in the respective legal orders.

\section{$A$ The Principle of Equality}

The first question to arise when studying the principle of non-discrimination in a given legal order is its relationship to the principle of equality. ${ }^{20}$ Generally speaking, equality and non-discrimination are positive and negative statements of the same principle. One is treated equally when one is not discriminated against and one is discriminated against when one is not treated equally.

Whereas traditional international law used not to concern itself with discrimination, except in relation to sovereignty, the Second World War triggered an unprecedented concern for human rights protection and led to guaranteeing them for all without discrimination. From the 1950s onwards, conventional guarantees of the non-discrimination principle multiplied. The principle of non-discrimination is now one of the most frequently protected norms of international human rights law. ${ }^{21}$ It is rarer, however, to find international legal guarantees of the principle of equality before and in the law. ${ }^{22}$ Both the ECHR and EU law diverge in this respect.

18 Of course, the ECJ might also be called to apply Article 14 ECHR qua indirect source of EU fundamental rights. For the sake of clarity, however, the case law of both Courts will only be studied with respect to the interpretation of their respective principles of non-discrimination.

19 For detailed comparative studies of those two regimes of non-discrimination in Europe, see, for example, Martin. supra n. 5; Anardottir, Equality and Non-discrimination under the European Convention on Human Rights (The Hague: Kluwer, 2003); and Hernu. Principe d'Égalité et Principe de Non-discrimination dans la Jurisprudence de la Cour de Justice des Communautés Européennes (Paris: LGDJ, 2003).

20 See McCrudden, 'Equality and Non-Discrimination', in Feldman, English Public Law (Oxford: Oxford University Press, 2004) Ch. 11.

21 See, for example, Article 2 Universal Declaration of Human Rights and Fundamental Freedoms 1948, GA Res. $217 \mathrm{~A}$ (III), A/810 at 71; Article 2(1), 3 and 26 International Covenant on Civil and Political Rights 1966, 999 UNTS 171; and Article 2(2) International Covenant on Economic, Social and Cultural Rights 1996, 993 UNTS 3.

22 See, for example, Article 7 Universal Declaration of Human Rights, supra n. 21. See Bayefsky, 'The Principle of Equality or Non-discrimination in International Law', (1990) 11 Human Rights Quarterly 5. 
EU law has always entailed both a general principle of equality before and in the law and a general principle of non-discrimination as two faces of the same coin. ${ }^{23}$ The EU fundamental principle of equality, that is a nonwritten and general principle of EU law, finds many further expressions qua non-discrimination principle(s) in primary and secondary EU law. ${ }^{24}$ This is the case, for instance, in the prohibition of discrimination on grounds of nationality (Article 12 Treaty establishing the European Community (EC)) or the principle of equal pay for equal work (Article $141 \mathrm{EC}$ ). It has recently been guaranteed expressly, however, in a quasi-constitutional manner in Article 20 of the EU Charter of Fundamental Rights, while Article 21 EU Charter protects the principle of non-discrimination. ${ }^{25}$ The complementarity and interchangeability between the principles of equality and non-discrimination in EU law have been confirmed in the case of the prohibition of gender discrimination, which is defined by Article 2(1) Directive 76/207/EEC as follows: 'the principle of equal treatment shall mean that there shall be no discrimination whatsoever on grounds of sex either directly or indirectly by reference in particular to marital or family status'. In any case, the relationship between equality and nondiscrimination remains ambiguous in EU law to the extent that, in the absence of a specific principle of non-discrimination, the principle of equality could not until recently be invoked directly in a case of discrimination. ${ }^{26}$

In contrast, Article $14 \mathrm{ECHR}^{27}$ only guarantees a non-discrimination principle in the exercise of other rights in the Convention. ${ }^{28}$ True, Article 14 ECHR has now been complemented by Protocol 12, which entered into force in 2005. This optional protocol establishes, for those 17 Contracting Parties

23 See Joined Cases 117/76 and 16/77, Albert Ruckdeschel E Co. and Hansa-Lagerhaus Ströh \& Co. v Hauptzollamt Hamburg-St. Annen; Diamalt AG v Hauptzollamt Itzehoe [1977] ECR 1753 at para. 7: 'This does not alter the fact that the prohibition of discrimination laid down in the aforesaid provision is merely a specific enunciation of the general principle of equality which is one of the fundamental principles of community law. This principle requires that similar situations shall not be treated differently unless differentiation is objectively justified. See Case C-147/ 03, Commission of the European Communities v Republic of Austria [2005] ECR I-5969 at para. 41. See Anardottir, supra n. 19 at 8; and Martin, supra n. 5 at 515-20.

24 See also, Lenaerts. 'Légalité de Traitement en Droit Communautaire - Un Principe Unique aux Apparences Multiples.' (1991) Cahiers de Droit Européen 3.

25 The Charter was re-promulgated on 14 December 2007 (with the revisions to the horizontal clauses adopted by the 2004 Treaty establishing a Constitution for Europe) and will become binding when the 2007 Lisbon Treaty enters into force (OJ 2007/C 303/01). See Bell, 'Equality and the European Union Constitution', (2004) 33 Industrial Law Journal 242.

26 See Martin, supra n. 5 at 515-29. Compare, however, Case C-144/04, Werner Mangold v Rüdiger Helm [2005] ECR I-9981 at para. 75; and Case C-300/04, Eman and Sevinger v College van burgemeester en wethouders van Den Haag [2006] ECR I-8055 at paras 57-8. See the discussion of the prohibited grounds of discrimination in EU law. subsequently.

27 Article 14 ECHR reads as follows: "The enjoyment of the rights and freedoms set forth in this Convention shall be secured without discrimination on any ground such as sex, race, colour, language, religion, political or other opinion, national or social origin, association with a national minority, property, birth or other status.'

28 See Livingstone, 'Article 14 and the Prevention of Discrimination in the European Convention on Human Rights', (1997) 1 European Human Rights Law Review 25; and Wildhaber, 'Protection against Discrimination under the European Convention on Human Rights - A Second-class 
which have ratified it to date, a principle of equality before and in the law. ${ }^{29}$ Those Contracting Parties only constitute a third of the Council of Europe's Member States, however, and the gap between ECHR and EU law remains intact in this respect. ${ }^{30}$

The explanation for this divergence may be found in the fundamental difference in nature between both legal orders. The EU legal order is autonomous and has already been constitutionalised in many respects, thus calling for the entrenchment of a strong equality protection clause (Article 20 EU Charter) besides its many non-discrimination principles. In contrast, the ECHR remains a minimal catalogue of fundamental rights whose exercise should be guaranteed in a non-discriminatory way; in those circumstances, Article 14 is thought of as minimal and subsidiary to national constitutional equal protection clauses (see Article 53 ECHR).

\section{B. The Principle of Non-discrimination}

Although non-discrimination is a dominant and recurrent theme of international human rights law, the principle is never defined in a single and uniform fashion in the different sources of international law. Nor do most of its guarantees provide a definition of its scope. ${ }^{31}$ Unsurprisingly, therefore, the ECHR and EU law diverge with respect to both the definition and the role they give to the non-discrimination principle.

Article 14 ECHR does not create an additional right not to be discriminated, ${ }^{32}$ but merely a principle that applies when the case at hand falls within the ambit of other rights in the Convention ('accessory' character of the principle). ${ }^{33}$ Although these rights need not be violated for Article 14 ECHR to be invoked ('autonomy' of the principle), its violation will not be examined by the

Guarantee?', (2002) 2 Baltic Yearbook of International Law 5, at 7. See also, van Dijk, van Hoof, van Rijn and Zwaak (eds). Theory and Practice of the European Convention on Human Rights (Antwerp: Intersentia, 2006) Ch. 33, at 1027.

29 Article 1(1) Protocol 12 reads as follows: '1. The enjoyment of any right set forth by law shall be secured without discrimination on any ground such as sex, race, colour, language, religion, political or other opinion, national or social origin. association with a national minority, property, birth or other status.' See van Dijk, van Hoof, van Rijn and Zwaak, supra n. 28 at Ch. 39, at 989.

30 See, for example, Khaliq, 'Protocol 12 to the European Convention on Human Rights: A Step Forward or a Step Too Far?', (2001) Public Law 457.

31 See Bayefsky, supra n. 22 at 34.

32 See, for example, Lambert, 'La Portée de l'Article 14 de la Convention Européenne des Droits de l'Homme'. (2003) Revue Hellénique des Droits de l'Homme 59.

33 See Abdulaziz, Cabales and Balkandali v United Kingdom A 94 (1985); (1985) 7 EHRR 471 at para. 71: Petrovic v Austria 1998-II 579; (2001) 33 EHRR 14 at para. 29; Sidabras and Dziautas v Lithuania (2006) 42 EHRR 6 at paras 47-8. See Lambert. 'Vers une Évolution de l'Interprétation de l'Article 14 de la Convention Européenne des Droits de l'Homme?', (1998) Revue Trimestrielle des Droits de l'Homme 497. See, however, Wintemute, "Within the Ambit": How Big is the "Gap" in Article 14 European Convention on Human Rights', (2004) 
Court when other rights in the Convention are actually regarded as being violated ('subsidiarity' of the principle). ${ }^{34}$ The only exceptions made by the ECtHR are in case of 'clear inequality of treatment ${ }^{35}$, although this criterion remains vague. ${ }^{36}$ of course, Protocol 12, for those few Contracting Parties which have ratified it, guarantees an independent non-discrimination principle since 2005. That principle is directly invocable independently from another right in the Convention and may be regarded as violated by the European Court even when other rights are.

In contrast, the principle of non-discrimination constitutes a leitmotiv in EU law. ${ }^{37}$ It lies at the core of the EU legal order and may, in its various concretisations, be invoked directly and autonomously both before national and European authorities. The principle of non-discrimination is a general principle of EU law that is non-written and was identified very early in the ECJ's case law. ${ }^{38}$ The principle has been concretised in primary and secondary law and it is through these multiple specific guarantees of the principle of nondiscrimination that it applies directly in national and EU law. ${ }^{39}$ Among its primary law guarantees, one should mention the prohibition of discrimination on grounds of nationality (Article $12 \mathrm{EC}$; further concretised in Articles 24, 39,42 and $49 \mathrm{EC}$ ) or the principle of equal pay for equal work (Article $141 \mathrm{EC}$ ). Since 2000, Article 21 of the EU Charter of Fundamental Rights protects the principle of non-discrimination, although this provision like the rest of the Charter remains non-binding despite its quasi-constitutional ambit. Article 13 EC, which was introduced by the Amsterdam Treaty in 1998, constitutes the legal basis for the adoption of further secondary law prohibiting discrimination on different grounds and in different areas of EU law. ${ }^{40}$ Gender discrimination

4 European Human Rights Law Review 366, arguing, by reference to Thlimmenos v Greece (2001) 31 EHRR 15 at para. 42 , that the fact that the ground of discrimination falls within the ambit of a Convention right is enough to apply Article 14 .

34 See Dudgeon v United Kingdom A 45 (1981); (1982) 4 EHRR 149 at para. 69. See Wildhaber. supra n. 28 at 7.

35 See Airey v Ireland (No1) A 32 (1979); (1979-80) 2 EHRR 305 at para. 30. See Lambert, supra n. 33 at $501-3$.

36 See Martin. supra n. 5 at 112.

37 See Advocate General Francis Jacobs' conclusions in Joined Cases C-92/92 and C-326/92, Phil Collins v Imtrat Handelsgesellschaft $\mathrm{GmbH}$ and Patricia Im- und Export Verwaltungsgesellschaft $m b H$ and Leif Emanuel Kraul v EMI Electrola GmbH [1993] ECR I-5145 at para. 9.

38 See, for example. Joined Cases 117/76 and 16/77. Albert Ruckdeschel $\&$ Co. and Hansa-Lagerhaus Ströh $\mathcal{E}$ Co. v Hauptzollamt Hamburg-St. Annen; Diamalt AG v Hauptzollamt Itzehoe [1977] ECR 1753 at para. 7 (in the case of nationality); and Case 149/77, Gabrielle Defrenne v Société anonyme belge de navigation aérienne Sabena [1978] ECR 1365 at paras 26-30 (in the case of gender).

39 See Lenaerts, supra n. 24.

40 Article $13 \mathrm{EC}$ reads as follows:

1. Without prejudice to the other provisions of this Treaty and within the limits of the powers conferred by it upon the Community, the Council, acting unanimously on a proposal from the Commission and after consulting the European Parliament, may take appropriate action to combat discrimination based on sex, racial or ethnic origin. religion or belief, disability, age or sexual orientation. 
at work and in services constitutes one of the areas where most directives have been adopted since the 1970 s, as we will see. One should also mention, however, the two general Directives adopted in 2000 on the basis of Article 13 $\mathrm{EC}^{41}$ the framework Directive 2000/78/EC on discrimination (on any ground) in the context of employment and occupation ${ }^{42}$ and the Directive 2000/43/EC prohibiting discrimination on grounds of ethnic or racial origin. ${ }^{43}$ The two directives have contributed to extending the non-discrimination principle to new grounds beyond nationality and sex and to new areas beyond employment and occupation. One may also regard this development as evidence of the progressive constitutionalisation of the principle in EU law.

As a result, while Article $14 \mathrm{ECHR}$ has only been regarded as violated in 20 decisions since 1968, the ECJ's case law entails countless decisions finding a breach of the non-discrimination principle. This difference may be explained by reference to the fundamental aims of both legal orders. Whereas the ECHR was meant to create a minimal catalogue of fundamental rights, the European legal order purported to create and sustain an internal market in which people could move and settle freely without discrimination of any kind. Of course, the justifications for the non-discrimination principle were mostly economic at first. The principle had as a primary aim to protect migrant workers and service providers against discrimination on grounds of nationality and this explains the central place of Article 12 in the EC Treaty and in the ECJ's case law. ${ }^{44}$ Gender discrimination was another form of discrimination that had to be prohibited from the very beginning under EU law, in order to prevent comparative economic advantages and social dumping among EU Member States. ${ }^{45}$ Nowadays, however, the principle of non-discrimination has turned into a social and even a human right in EU law and has therefore been extended since the end of the 1990s to encompass further grounds of discrimination whose connection to the internal market is rather indirect (see Article 13 EC and Directives 2000/78/EC and 2000/43/EC). ${ }^{46}$

Interestingly, neither European Court refers to the ratio legis of the nondiscrimination principle they are called upon to apply and hence to the reasons behind their divergence relative to the specific elements and implementation

41 See Schiek, 'A New Framework on Equal Treatment of Persons in EC law? Directives 2000/43/ EC, 2000/78/EC and 2002/73/EC', (2002) 8 European Law Journal 290.

42 Directive 2000/78/EC establishing a general framework for equal treatment in employment and occupation, [2000] OJ L 303/16.

43 Directive 2000/43/EC implementing the principle of equal treatment between persons irrespective of racial or ethnic origin, [2000] OJ L 180/22.

44 See, for example, Case 251/83. Eberhard Haug-Adrion v FrankfurterVersicherungs-AG [1984] ECR 4277 at para. 14.

45 See Intergovernmental Committee on European Integration. The Brussels Report on the General Common Market (English translation of a document commonly called the 'Spaak Report'), June 1956, at 15: available at: http://aei.pitt.edu/995/01/Spaakreport.pdf [last accessed 18 June 2008].

See McCrudden and Kountouros, supra n. 4. 
of the principle. This is particularly problematic in the case of EU law as the multiplicity of guarantees of the principle of non-discrimination applicable depending on the grounds of discrimination and on the area of application, on the one hand, together with the diversity of their sources in EU law and hence the variation of their impact on national law, on the other hand, make for a particularly complex and largely incoherent regime of anti-discrimination law.

\section{The Principle of Non-discrimination on Grounds of Gender}

To understand how gender discrimination is prohibited under EU and ECHR law, it is useful to start by discussing the source and role of the principle itself, before going on to study its personal and material scope, its constitutive material and procedural elements and different specific features it may have in practice.

\section{A. Source and Role}

The principle of non-discrimination on grounds of gender may, depending on the legal order, be guaranteed in many different sources, legislative or constitutional, and it may have a very different role from one legal order to the next. This difference in terms of sources and role is particularly evident from a comparison between ECHR and EU law on gender discrimination.

Gender is one among the many explicit grounds of discrimination prohibited under Article 14 ECHR and Protocol 12. As a result, the principle of nondiscrimination on grounds of gender is not a distinct principle in the European Convention, but merely a case of the general principle of nondiscrimination. Since that principle is still largely accessory in the Convention, the principle of non-discrimination on grounds of sex remains a second-class guarantee under ECHR law. ${ }^{47}$ Of course, the ECtHR's case law entails important cases of gender discrimination where it has developed a more detailed regime of non-discrimination on grounds of sex. The first case of application of Article 14 ECHR to sex discrimination only dates back, however, to 1985 and was decided against the United Kingdom in the context of immigration restrictions. ${ }^{48}$ Overall, the ECtHR's decisions remain too few to constitute a

47 See on Article 14 qua second-class guarantee, Wildhaber, supra n. 28. See, however, for recent efforts by the ECtHR to systematise its case law, Zarb Adami v Malta (2006) 44 EHRR 3 at paras 78 and 82-3 (indirect sex discrimination) and D.H. and others v Czech Republic, Application No. 57325/00, Judgment of 2007 (indirect race discrimination).

48 Abdulaziz, Cabales and Balkandali v United Kingdom A 94 (1985); (1985) 7 EHRR 471 at para. 78 : 'As to the present matter, it can be said that the advancement of the equality of the sexes is today a major goal in the member States of the Council of Europe.' [emphasis added]. 
complete regime of ECHR sex discrimination law and, despite a recent tendency to systematisation, the Court's casuistic approach has led to a regrettable lack of coherence overall.

In EU law, gender-based discrimination is protected against by an express and specific principle of non-discrimination in primary law. As alluded to before, discrimination on grounds of sex was prohibited for economic reasons from the creation of the Common Market in 1957; it constituted an economic comparative advantage in favour of those countries with low social protection and had to be prohibited to ensure fair competition among Member States. As a result, it was prohibited expressly in the 1957 EEC Treaty, albeit quite restrictively qua principle of equal pay for equal work in Article 119 (now Article 141 EC). Rapidly, however, that principle was granted direct effect by the ECJ in its famous Defrenne II case. ${ }^{49} \mathrm{~A}$ few years later, the principle of equality between men and women was even recognised as a general principle of EU law and more precisely as a fundamental right of EU law by the ECJ in the Defrenne III case. ${ }^{50}$ Nowadays, equality between men and women constitutes one of the EU's goals described in Articles 2 and $3 \mathrm{EC}$. The principle of non-discrimination on grounds of sex is also guaranteed as such in Article 23 of the (non-binding to date) EU Charter of Fundamental Rights. Since the general principle of non-discrimination on grounds of gender is not invocable per se, the only expression of the principle that can be applied directly at the moment is Article $141 \mathrm{EC}$.

From 1975 onwards, various directives were adopted to concretise the principle, mostly in the context of employment and occupation ${ }^{51}$ but also, since 2004, on the basis of Article $13 \mathrm{EC}$, in the area of supply of goods and services. $^{52}$ One of the first directives to be adopted was the Directive 76/207/EEC

49 Case 43/75, Gabrielle Defrenne v Société Anonyme Belge de Navigation Aérienne Sabena [1976] ECR 455 at para. 40.

50 Case 149/77, Gabrielle Defrenne v Société Anonyme Belge de Navigation Aérienne Sabena [1978] ECR 1365 at paras 26-30: "The court has repeatedly stated that respect for fundamental personal human rights is one of the general principles of community law, the observance of which it has a duty to ensure. There can be no doubt that the elimination of discrimination based on sex forms part of those fundamental rights.' [emphasis added] See for a recent case on the same issue, Joined Cases C-231/06, 232/06 and 233/06, Office national des pensions $v$ Emilienne Jonkman, Hélène Vercheval and Noëlle Permesaen v Office national des pensions [2007] ECR I-5149.

51 See, for example. Directive 75/117/EEC on the approximation of the laws of the Member States relating to the application of the principle of equal pay for men and women, [1975] OJ L 45; Directive 79/7/EEC on the progressive implementation of the principle of equal treatment for men and women in matters of social security, [1979] OJ L 6; Directive 86/378/EEC on the implementation of the principle of equal treatment for men and women in occupational social security schemes, [1986] OJ L 225; Directive 86/613/EEC on the application of the principle of equal treatment between men and women engaged in an activity, including agriculture, in a self-employed capacity and on the protection of self-employed women during pregnancy and motherhood, [1986] OJ L 359; and Directive 96/34/EC on the framework agreement on parental leave, [1996] OJ L 145.

52 Directive 2004/113/EC implementing the principle of equal treatment between women and men in the access to and supply of goods and services, [2004] Of L 373/37. 
on the equality between men and women in employment and occupation. It was revised completely in 2002 to be adapted to the development of the case law and to the 2000/78 framework Directive on equality in employment and occupation. ${ }^{53}$ One should also mention Directive 97/80/EC that alleviates the burden of proof of sex discrimination. ${ }^{54}$ In 2006 , a recast Directive 2006/54/EC on the equality between men and women in employment and occupation was finally adopted to group in the same directive all previous directives relative to gender discrimination at work. ${ }^{55}$ By 15 August 2008, the 2006 Directive should be fully implemented in all Member States and by 15 June 2009, previous directives in the context of gender discrimination, including Directives $76 / 207 / \mathrm{EEC}$ and $97 / 80 / \mathrm{EC}$, shall be repealed. ${ }^{56}$ Last but not least, the ECJ was the most important promoter of equality between men and women in the 1980s and 1990s. As a matter of fact, the 2002 revision of the Directive 76/207/EEC, as well as the 2006/54/EC recast Directive codifies some of the achievements of the ECJ's case law into EU secondary law.

In comparison, the centrality of the prohibition of gender discrimination in EU law has not resulted in greater conceptual clarity in the ECJ's case law and does not guarantee a more systematic approach to violations than in the ECtHR's. On the contrary, the multiplicity of principles of non-discrimination and matching regimes depending on the ground of discrimination ${ }^{57}$ has given rise to many discrepancies that are not always acknowledged or explained by the Court. The same applies to the principle of gender discrimination that has many sources and accordingly many personal and material scopes. ${ }^{58}$ This multiplicity of regimes is reflected in the impact of the different principles on national law. For instance, for a long time, to be able to invoke the principle of equality between men and women directly, men and women had to invoke the equal pay principle (Article $141 \mathrm{EC}$ ) and prove that their case was a case

53 Directive $76 / 207 / \mathrm{EEC}$ on the implementation of the principle of equal treatment for men and women as regards access to employment, vocational training and promotion, and working conditions. [1976] OJ L 39 (revised by Directive 2002/73/EC to extend the principle to all kinds of work and all working conditions, [2002] OJ L 269).

54 Directive 97/80/EC on the burden of proof in cases of discrimination based on sex. [1998] OJ L 14.

55 Directive 2006/54/EC on the implementation of the principle of equal opportunities and equal treatment of men and women in matters of employment and occupation. [2006] OJ L 204.

56 Given the delay before the complete implementation of Directive 2006/54/EC and the repeal of others, the present article discusses both existing guarantees and Directive 2006/54/EC.

57 See, for example, Waddington and Bell, 'More Equal than Others: Distinguishing European Union Equality Directives', (2001) 38 Common Market Law Review 587. See also, Lenaerts. supra n. 24.

58 See, for example, Schiek, 'Broadening the Scope and the Norms of EU Gender Equality Law: Towards a Multi-Dimensional Conception of Equality Law', (2005) 12 Maastricht Journal of European and Comparative Law 427. 
of equal pay for equal work. ${ }^{59}$ Other discrepancies exist relative to the principle of non-discrimination on grounds of gender's material and personal scope depending on its specific sources.

\section{B. Scope}

The personal scope of a principle refers to the group of its beneficiaries and addressees, while its material scope relates to its domains of application. The principle of non-discrimination on grounds of gender has a different personal and material scope under ECHR and EU law.

The personal scope of the principle as it is guaranteed in Article 14 ECHR encompasses all physical and legal persons qua beneficiaries (Article 34 ECHR). Its addressees are States Parties and their authorities and the principle does not bind other individuals directly (Article 34 ECHR). Article 14's horizontal effect is at the most indirect therefore and goes via Contracting Parties' positive duties to protect ECHR rights against both state and individual violations. ${ }^{60}$ The same can be said of Article 1 Protocol 12. Under EU law, in contrast, those protected by the principle of non-discrimination on grounds of gender include all physical and legal persons, while the addressees are both state authorities and individuals. Note, however, that the personal scope of the principle varies depending on its legal source in EU law. Thus, the addressees of the equal pay principle of Article 141(1) EC include individuals and the principle is accordingly given as a direct horizontal effect, ${ }^{61}$ while it is not the case of the right to derogate to formal equality according to Article 141(4) EC or Article 2(8) of the Directive 76/207/EEC. Interestingly, moreover, the lack of prima facie direct effect of directives in EU law prevents them from being invoked directly by individuals against other individuals outside of an equal pay context. ${ }^{62}$

Under Article 14 ECHR, the principle's material scope is broad and encompasses all areas of national law provided one of the Convention rights applies. Under EU law, in contrast, the principle of equality between men and women only applies to the areas in which it is said to apply, such as employment for most guarantees since 1975 or recently services and the supply of goods for Directive 2004/113/EC. Even qua guarantee of a general fundamental principle,

59 See, for example, the discussion in Case 149/77, Gabrielle Defrenne v Société Anonyme Belge de Navigation Aérienne Sabena [1978] ECR 1365; and Case C-147/95, Dimossia Epicheirissi llektrismou (Dei) v Efthimios Evrenopoulos [1997] ECR I-2057. See Waddington, "Testing the Limits of the EC Treaty Article on Non-discrimination', (1999) 28 Industrial Law Journal 133.

60 See, for example, Pla and Puncernau v Andorra (2006) 42 EHRR 25.

61 See, for example, Case 149/77, Gabrielle Defrenne v Société Anonyme Belge de Navigation Aérienne Sabena [1978] ECR 1365.

62 See supra n. 59. 
the principle only applies in areas belonging to the material scope of the EC Treaty. ${ }^{63}$

\section{Material Constitutive Elements}

Broadly speaking, the principle of non-discrimination precludes treating differently similar situations and treating equally different situations unless this differential treatment is objectively justified. While both European principles of non-discrimination on grounds of sex could fit this general definition, important variations arise inside each of the constitutive material elements of a discrimination. In a nutshell, the latter are: (i) an unfavourable treatment (ii) of comparable cases (iii) based on a prohibited ground of discrimination (iv) that cannot be objectively justified. ${ }^{64}$

\section{(i) Unfavourable treatment}

The unfavourable treatment that constitutes the first element of a case of discrimination consists either in the different treatment of similar situations or in the equal treatment of different situations. Both types of unfavourable treatment are precluded by the ECHR and EU law.

According to the ECtHR, Article 14 of the Convention not only requires that persons in a similar situation must be treated in an equal manner but also requires that persons whose situations are significantly different must be treated differently. ${ }^{65}$ This is also what applies in EU law. According to the ECJ, the principle of non-discrimination on grounds of nationality and mutatis mutandis that of non-discrimination on grounds of sex require that persons in a similar situation must be treated in an equal manner, but also that persons whose situations are significantly different must be treated differently. ${ }^{66}$

The unfavourable treatment can be overt or direct when it is openly founded on gender or covert or indirect, when it is founded on a neutral criterion (same burden in law), but which results in having a greater impact on those of one sex than the other (different burden in fact). ${ }^{67}$

63 See, for example. Case 43/75, Gabrielle Defrenne v Société anonyme belge de navigation aérienne Sabena [1976] ECR 455. This also applies to other grounds of discrimination and to Articles 12 and 13 EC (Case C-291/96, Criminal proceedings against Martino Grado and Shahid Bashir [1997] ECR I-5531). See Waddington, supra n. 59 at 136.

64 One retrieves these elements in the case law of both Courts: see Joined Cases 117/76 and 16/77, Albert Ruckdeschel $\mathcal{E}$ Co. and Hansa-Lagerhaus Ströh $\mathcal{E}$ Co. v Hauptzollamt Hamburg-St. Annen; Diamalt AG $v$ Hauptzollamt Itzehoe [1977] ECR 1753 at para. 7, and Koua Poirrez $v$ France (2005) 40 EHRR 2 at para. 46.

65 Hoogendijk v Netherlands (2005) 40 EHRR SE22 at 206. See also, ECtHR, Thlimmenos v Greece (2001) 31 EHRR 15 at para. 47.

66 See Case 251/83, Eberhard Haug-Adrionv FrankfurterVersicherungs-AG [1984]ECR 4277 at para.14.

67 On the notion of indirect discrimination in EC law, see Tobler, Indirect Discrimination. A Case Study into the Development of the Legal Concept of Indirect Discrimination under EC Law (Antwerp: Intersentia, 2005). 
This distinction was first made by the $\mathrm{ECJ}$ in its case law and has become a fundamental distinction in EU anti-discrimination law and especially in gender non-discrimination law. ${ }^{68}$ Examples abound in the ECJ's case law. A frequent case of prohibited direct discrimination is discrimination on grounds of pregnancy ${ }^{69}$, while a common case of precluded indirect discrimination is the less advantageous treatment in terms of pay, further training rights or pension schemes of part-time workers who happen to be mostly women. ${ }^{70}$ The ECJ has opted for different definitions of indirect discrimination depending on the ground. In the context of discrimination based on nationality, the Court used to require evidence of a real disadvantage of the allegedly discriminatory measure on non-nationals ${ }^{71}$ and has recently considered that there could be indirect discrimination in case of mere liability of disadvantage for a higher proportion of non-nationals. ${ }^{72}$ In the context of gender discrimination, the ECJ has chosen yet another definition, since it equates indirect discrimination with the impact on a considerably higher proportion of women or men. ${ }^{73}$ This solution is said to have been modelled on the definition of private indirect discrimination prohibited by Title VII of the US Civil Rights Act $1964 .{ }^{74}$ On the basis of the ECJ's case law, the notion of indirect discrimination was codified in the Burden of Proof Directive 97/80/EC in $1997^{75}$ and redefined in the context of discrimination in general in Article 2(2) Directives 2000/43/EC

68 See Martin, supra n. 5 at 87-91, 159-63.

69 See Case C-177/88, Elisabeth Johanna Pacifica Dekker v Stichting Vormingscentrum voor Jong Volwassenen (VJV-Centrum) Plus [1990] ECR I-3941 at paras 10-4; and Case C-179/88, Handels- og Kontorfunktionaerernes Forbund i Danmark v Dansk Arbejdsgiverforening (Hertz) [1990] ECR I-3979 at paras 13-9.

70 See Case 96/80, J.P. Jenkins v Kingsgate (Clothing Productions) Ltd [1981] ECR 911 at paras 11-5, and Case 170/84, Bilka-Kaufhaus GmbH v Karin Weber von Hartz [1986] ECR 1607 at paras 24-31.

71 Case 152/73, Giovanni Maria Sotgiu v Deutsche Bundespost [1974] ECR 153 at paras 12-3.

72 Case C-237/94, John O'Flynn vAdjudication Officer [1996] ECR I-2617 at paras 18-21.

73 Case 96/80, J.P. Jenkins v Kingsgate (Clothing Productions) Ltd [1981] ECR 911 at para. 13; Case 170/84, Bilka-Kaufhaus GmbH v Karin Weber von Hartz [1986] ECR 1607 at para. 29; Case 171/ 88, Ingrid Rinner-Kühn v FWW Spezial-Gebäudereinigung GmbH \& Co. KG [1989] ECR 2743 at para. 11; and Case C-226/98, Birgitte Jergensen $v$ Foreningen af Specialleger and Sygesikringens Forhandlingsudvalg [2000] ECR I-2447 at para. 19.

74 See on the American notion of 'disparate impact', Griggs v Duke Power Co 401 US 424, $91 \mathrm{~S}$ Ct 849 (1971) and Dothard $v$ Rawlinson 433 US 321, 97 S Ct 2720 (1977). Interestingly, the Dothard test is in favour of women in case of private indirect discrimination and contrasts with the evidence of discriminatory intent that is required in the case of state indirect discrimination in US law. In EU law, however, opting for a disparate impact approach in contrast to the individual disadvantage approach in Case 152/73. Giovanni Maria Sotgiu v Deutsche Bundespost [1974] ECR 153, or even the likelihood of disadvantage approach in Case C-237] 94, John O'Flynn v Adjudication Officer [1996] ECR I-2617 is not necessarily a more favourable solution. See Martin, supra n. 5 at $88-90$ for a detailed discussion.

75 Article 2(2) Directive 97/80/EC reads:

For purposes of the principle of equal treatment referred to in paragraph 1 , indirect discrimination shall exist where an apparently neutral provision. criterion or practice disadvantages a substantially higher proportion of the members of one sex unless that provision, criterion or practice is appropriate and necessary and can be justified by objective factors unrelated to sex. (emphasis added). 
and 2000/78/EC. ${ }^{76}$ Nowadays, for the sake of coherence, the concepts of direct and indirect discrimination have been redefined in the context of gender discrimination by Article 2(2) Directive 76/207/ $\mathrm{EEC}^{77}$ and Article 2(2) Directive $2006 / 54 / \mathrm{EC}^{78}$ A certain lack of clarity remains, however, regarding the different versions of the definition of indirect discrimination between the directives; it is unclear whether the notions of disadvantage for 'a substantially higher proportion of persons of one sex' and that of 'particular disadvantage' for persons of one sex are comparable at all. ${ }^{79}$

Indirect discrimination is less thematised under Article 14 ECHR. For a long time, the distinction between direct and indirect discrimination was even absent from the ECtHR's case law. ${ }^{80}$ It has become clear from the ECtHR's recent case law, however, that both direct and indirect discrimination are prohibited. According to the Court in the Hoogendijk case, 'where a general policy

76 Article 2(2) Directive 2000/78/EC reads:

(a) direct discrimination shall be taken to occur where one person is treated less favourably than another is, has been or would be treated in a comparable situation, on any of the grounds referred to in Article 1; (b) indirect discrimination shall be taken to occur where an apparently neutral provision, criterion or practice would put persons having a particular religion or belief, a particular disability, a particular age, or a particular sexual orientation at a particular disadvantage compared with other persons unless: (i) that provision, criterion or practice is objectively justified by a legitimate aim and the means of achieving that aim are appropriate and necessary, or (ii) as regards persons with a particular disability, the employer or any person or organisation to whom this Directive applies, is obliged, under national legislation, to take appropriate measures in line with the principles contained in Article 5 in order to eliminate disadvantages entailed by such provision, criterion or practice. (emphasis added)

77 Article 2(2) Directive 76/207/EEC reads:

For the purposes of this Directive, the following definitions shall apply: - direct discrimination: where one person is treated less favourably on grounds of sex than another is, has been or would be treated in a comparable situation, - indirect discrimination: where an apparently neutral provision, criterion or practice would put persons of one sex at a particular disadvantage compared with persons of the other sex, unless that provision, criterion or practice is objectively justified by a legitimate aim, and the means of achieving that aim are appropriate and necessary .... (emphasis added)

See Ahtela, "The Revised Provisions on Sex Discrimination in European Law: A Critical Assessment', (2005) 11 European Law Journal 57.

78 Article 2(2) Directive 2006/54/EC reads:

(a) "direct discrimination": where one person is treated less favourably on grounds of sex than another is, has been or would be treated in a comparable situation; (b) "indirect discrimination": where an apparently neutral provision, criterion or practice would put persons of one sex at a particular disadvantage compared with persons of the other sex. unless that provision, criterion or practice is objectively justified by a legitimate aim, and the means of achieving that aim are appropriate and necessary. (emphasis added)

79 See Martin, supra n. 5 at 210, note 552 as the French and English versions differ in this respect.

80 See, for example, Martin, supra n. 5 at 113. 
or measure has disproportionately prejudicial effects on a particular group, it is not excluded that this may be regarded as discriminatory notwithstanding that it is not specifically aimed or directed at that group. ${ }^{81}$ Generally speaking, and well before that decision, the definition of discrimination used by the ECtHR was broad and its notion of direct discrimination lato sensu could be said to encompass indirect discrimination. ${ }^{82}$

\section{(ii) Comparability of cases}

For differential treatment to be deemed discriminatory, it needs to be treating comparable cases differently or treating non-comparable cases equally. If the cases are not comparable, the difference of treatment does not need to be justified and is not discriminatory. Assessing the comparability of the situations at hand is a crucial stage; depending on the standard chosen to assess the comparability of the cases and hence on the identification of the compared groups, the situations will be deemed comparable or not, thus leading to a further enquiry or to the dismissal of the application. Both the ECJ and the ECtHR have recognised the importance of the comparability phase, but both also often tend to elude it in view of its difficulty in practice.

Under EU gender discrimination law, the comparability is an important condition of discrimination. The ECJ is usually more willing to test the comparability of the situations at hand in cases of gender discrimination than of discrimination on other grounds. ${ }^{83}$ Even in equal pay cases, however, where comparability is regarded as essential, ${ }^{84}$ the ECJ does not provide a very precise definition of the notion of comparability and its test is not always very strict. $^{85}$ The Grant case, for instance, has shown the latter's limits; in that case, the ECJ compared the situation of a lesbian woman to that of a homosexual man and concluded the absence of discrimination! ${ }^{86}$

In contrast, the ECtHR almost systematically postpones the assessment of comparability of the situations at hand to the justification phase. ${ }^{87}$ There are

81 Hoogendijk v Netherlands (2005) 40 EHRR SE22 at 207. See also, most recently, Zarb Adami v Malta (2006) 44 EHRR 3 at paras 78 and 82-3 (indirect sex discrimination) and D.H. and others v Czech Republic Application No. 57325/00. Judgment of 2007, at paras 179-80 and 187-95 (indirect race discrimination).

82 See Martin, supra n. 5 at 285.

83 See Martin, supra n. 5 at $151-3$.

84 See, for example, Case C-226/98, Birgitte Jorgensen $v$ Foreningen af Speciallegger and Sygesikringens Forhandlingsudvalg [2000] ECR I-2447 at paras 27-33.

85 See, for example, Case C-309/97, Angestelltenbetriebsrat der Wiener Gebietskrankenkasse vWiener Gebietskrankenkasse [1999] ECR I-2865 at para. 17.

86 See Case C-249/96, Lisa Jacqueline Grant v South-West Trains Ltd [1998] ECR I-621 at para. 27.

87 See Rasmussen v Denmark A 87 (1984); (1984) 7 EHRR 371 at para. 37, where the Court said: 'The Court does not consider that it has to resolve this issue, especially as the positions and interests referred to are also of relevance in determining whether the difference of treatment was justified. It will proceed on the assumption that the difference was made between persons placed in analogous situations.' 
a few exceptions, of course, as when the lack of comparability is used to dismiss a case. ${ }^{88}$ However, when the Court compares the situations, its test is often reduced to a minimum. Sometimes, it even uses the measure of comparability as a justification for the differential treatment, thus undermining the whole discrimination test. ${ }^{89}$

\section{(iii) Ground of discrimination}

Differential treatment of comparable cases is usually only regarded as discriminatory if the ground on which the differential treatment is based constitutes a prohibited ground of discrimination. What constitutes such a ground varies between Article 14 ECHR and EU law.

Under Article 14 ECHR, the grounds mentioned are only exemplary and any characteristic related to one's personality or one's given personal features may be regarded as a prohibited ground of discrimination. ${ }^{90}$ Thus, while sexual orientation ${ }^{91}$ and transsexuality ${ }^{92}$ were not among the grounds expressly mentioned in Article 14 ECHR, they have all been deemed prohibited grounds by the ECtHR -although not always directly on the basis of Article 14 but of Article 8 ECHR. Discrimination on grounds of sex is expressly prohibited by Article 14 ECHR. In fact, sex is not only a prohibited ground of discrimination, but it is considered a suspect classification requiring heightened scrutiny by the Court when assessing the justification of a sex-based discrimination. ${ }^{93}$ This is also the case of discrimination based on sexual orientation, which requires very weighty reasons to be justified..$^{94}$ In this respect, the ECtHR's case law may be compared to that of the US Supreme Court that has developed various categories of suspect classifications and corresponding levels of scrutiny by the Court; gender is peculiar in this respect as it is not generally classified as a suspect classification like race and only requires an intermediate level of scrutiny by the US Supreme Court. ${ }^{95}$

EU law is more restrictive, however, as to the prohibited grounds of discrimination. Those grounds have gradually been identified by EU primary and secondary law. The recognition of the non-discrimination principle qua

88 Beale v United Kingdom (2005) 40 EHRR SE6.

89 See, for example, Stubbings and others v United Kingdom 1996-IV; (1997) 23 EHRR 213 at para. 74 .

90 See Sidabras and Dziautas v Lithuania (2006) 42 EHRR 6 (see Judge Thomassen).

91 Dudgeon v United Kingdom A 45 (1981); (1981) 4 EHRR 149; Salgueiro de Silva Mouta v Portugal (2001) 31 EHRR 47; and Fretté v France (2004) 38 EHRR 21.

92 Christine Goodwin v United Kingdom 2002-VI; (2002) 35 EHRR 18 at paras 90-3 (albeit not directly on grounds of Article 14 ECHR).

93 See Abdulaziz, Cabales and Balkandali v United Kingdom A 94 (1985); (1985) 7 EHRR 471 at para. 78; and Burghartz v Switzerland A 280A (1994); (1994) 18 EHRR 101 at para. 27.

94 See $L$ and $V$ vAustria (2003) 36 EHRR 55 at para. 45.

95 See United States $v$ Virginia, 518 US 515, 116 S Ct 2264 (1996) and Mississippi University for Women $v$ Hogan. 458 US 718, 102 S Ct (1982). 
fundamental right of EU law did not change anything in this respect, because that principle could not until recently be invoked directly independently from a primary or secondary legal provision. ${ }^{96}$ New lists of prohibited grounds of discrimination developed after 2000 and in particular in Article $13 \mathrm{EC}$, Article 21 EU Charter and Article 1 Directive 2000/78/EC. Gender discrimination has been expressly prohibited by a number of specific primary and secondary law provisions since 1957 and it is reiterated in the lists of Article 13 EC and Article 23 EU Charter. Gender was regarded by the ECJ as including gender reassignment in the $P v S$ case. ${ }^{97}$ The Court refused, however, to extend its reasoning to discrimination on grounds of sexual orientation in the Grant case. ${ }^{98}$ Nowadays, sexual orientation is prohibited as a self-standing ground of discrimination without having to be attached to gender (Article 13 EC, Article 21 EU Charter and Article 1 Directive 2000/78/EC). ${ }^{99}$

In contrast to the ECtHR's case law, there are no grounds that are deemed more suspect than others under EU law. In principle, all prohibited grounds of discrimination should give rise to the same level of scrutiny by the ECJ. There are, however, variations between the tests used in cases of discrimination on grounds of nationality and sex discrimination and they demonstrate the higher protection granted to nationality; one may mention in this respect the kind of evidence required or the scope of the margin of appreciation allowed to Member States. ${ }^{100}$ Moreover, the ECJ seems to have introduced some kind of hierarchy in its recent case law relative to Directive 2000/78/EC. In the Mangold case, for instance, the test applied to age discrimination reflects a higher level of scrutiny than the test that would be applied to a similar case of sex discrimination. ${ }^{101}$ of course, the largely pragmatic and casuistic nature of the ECJ's approach in those matters makes it difficult to draw any general

96 For a critique, see Martin, supra n. 5 at 515-20. Compare, however, with Case C-144/04, Werner Mangold v Rüdiger Helm [2005] ECR I-9981 at para. 75, and Case C-300/04, Eman and Sevinger v College van burgemeester en wethouders van Den Haag [2006] ECR I-8055 at paras 57-8.

97 Case C-13/94, $P$ v S and Cornwall County Council [1996] ECR I-2143 at paras 17-22.

98 Case C-249/96, LisaJacqueline Grant v South-WestTrains Ltd [1998] ECR I-621 at paras 25-8, 29-36 and 37-42. See Bell,'Shifting Conceptions of Sexual Discrimination at the Court of Justice: From $P v S$ to Grant v SWT', (1999) 5 European Law Review 63. See also, Martin, supra n. 5 at 177-83.

99 Interestingly, the ECJ argued in Case C-144/04, Werner Mangold v Rüdiger Helm [2005] ECR I-9981 at para. 75, that age discrimination was prohibited qua general principle of EU law well before Directive 2000/78/EC, but had refused to recognise that this was the case for sexual orientation two years before the adoption of the Directive (Case C-249/96, Lisa Jacqueline Grant $v$ South-West Trains Ltd [1998] ECR I-621). See for a recent application, Case C-267/06, Tadao Maruko v Versorgungsanstalt der deutschen Bühnen [2008] ECR at paras 65-73.

100 See Martin, supra n. 5 at 220 for the same conclusion.

101 Case C-144/04, Werner Mangold v Rüdiger Helm [2005] ECR I-9981 at para. 65. See also, most recently in the case of disability, Case C-13/05. Sonia Chacón Navas $v$ Eurest Colectividades SA [2006] ECR I-6467 and Case C-303/06, S. Coleman v Attridge Law and Steve Law OJ 2008/C 223/08; [2008] ECR, unreported. See Martin, supra n. 13 at 129; Martin. 'Larrêt Mangold - Vers une Hiérarchie Inversée du Droit à l'Égalité en Droit Communautaire?', (2006) Journal des Tribunaux du Travail 109. 
and definitive conclusion as to the existence of a hierarchy of grounds of discrimination in the current state of EU law. ${ }^{102}$

\section{(iv) Justifications}

A differential treatment of comparable cases on prohibited grounds is only discriminatory when it cannot be justified by objective reasons. Some guarantees of the principle of non-discrimination on grounds of gender do not allow for justified restrictions, however. This divergence of approaches can be found between Article 14 ECHR and EU law.

Although Article 14 ECHR does not expressly foresee the possibility of justified restrictions, the ECtHR's case law allows for objective and reasonable justifications to be provided. According to the ECtHR, a distinction is discriminatory, for the purposes of Article 14, if it "has no objective and reasonable justification", that is if it does not pursue a "legitimate aim" or if there is no "reasonable relationship of proportionality between the means employed and the aim sought to be realised". ${ }^{103}$ Accordingly, the two conditions for the justification of a prima facie discrimination are: (i) a legitimate aim and (ii) proportionality between that aim and the means employed. The test also applies to gender discrimination. ${ }^{104}$ The case law has not developed a precise test of what a legitimate aim should be and it amounts at the most to a test of reasonableness. Moreover, the Court often conflates the assessment of the legitimate aim with the proportionality test. ${ }^{105}$ Justifications may be provided both in cases of direct and indirect gender discrimination. ${ }^{106}$

EU law distinguishes between the justification of direct and indirect gender discrimination. Whereas indirect discrimination on grounds of sex may be justified, it is never the case for direct sex discrimination. ${ }^{107}$ In this sense, gender is treated differently from other grounds and especially from nationality since both cases of direct and indirect discrimination on grounds of nationality may be justified. ${ }^{108}$ Recently, however, doubts have started arising in light of the justification clause of Article 2(5) Directive 2000/78/EC. Although the

102 See Schiek, supra n. 41 at 308-11, and Martin, supra n. 5 at 547. Cf Bell, supra n. 25 at 242 and 256.

103 Koua Poirrez v France (2005) 40 EHRR 2 at para. 46.

104 See Petrovic vAustria (2001) 33 EHRR 14 at para. 37; Abdulaziz, Cabales and Balkandali v United Kingdom A 94 (1985); (1985) 7 EHRR 471 at para. 78; and Burghartz v Switzerland (1994) 18 EHRR 101 at para. 27.

105 See, for example, Abdulaziz, Cabales and Balkandali v United Kingdom A 94 (1985); (1985) 7 EHRR 471 at para. 88. See Martin, supra n. 5 at $268-70$.

106 See Petrovic v Austria (2001) 33 EHRR 14 at paras 36-8.

107 See Case C-147/95. Dimossia Epicheirissi Ilektrismou (DEI) v Efthimios Evrenopoulos [1997] ECR I-2057 at paras $25-9$.

108 See, for example, Case C-415/93, Union Royale Belge des Sociétés de Football Association and Others $v$ Bosman and others [1995] ECR I-4921 at para. 104. 
framework directive applies to all grounds of discrimination prohibited by EU law, and this may explain its broad justification clause, it may be interpreted to mean that gender discrimination can be justified like discrimination on any other ground. ${ }^{109}$ Indirect gender discrimination may be justified by objective grounds unrelated to sex provided they are proportionally related to the means chosen. ${ }^{110}$ According to the ECJ in the Bilka case, this is the case when 'the means chosen [...] correspond to a real need on the part of the undertaking, are appropriate with a view to achieving the objective in question and are necessary to that end. ${ }^{111}$ On the model of the American Civil Rights Act 1964 's notion of 'bona-fide-occupational-qualification', these objective grounds encompass economic and non-economic grounds provided they are not sex-related. The ECJ is traditionally very generous in granting those grounds, especially when Member States' or the European Community's social policies are at stake. ${ }^{112}$

Under the ECHR, when the ground of discrimination is a suspect one, it is more difficult to justify a discriminatory measure. Because sex is a suspect ground under Convention law only, the two regimes differ in this respect. Since gender is a suspect ground of discrimination under Article 14 ECHR, the Contracting Parties are required to provide 'very weighty reasons' for the differential treatment to be justified. ${ }^{113}$ This is also the case for prima facie discriminations founded on sexual orientation. ${ }^{114}$ The Court has not developed a clear test of what these very weighty reasons could be, however. Moreover, the fact that Contracting Parties have been granted a broad margin of appreciation in cases of gender discrimination, especially when it comes to general measure of economic and social strategy, has in practice contributed to the dilution of the 'very weighty reasons' requirement. ${ }^{115}$

Under EU law, in the absence of suspect classifications, justifications of gender discriminations are treated like those of any other kind of

109 This seems to be confirmed moreover by the hesitations of the ECJ in its decisions in Case C-152/91, David Neath v Hugh Steeper Ltd [1993] ECR I-6935 and Case C-109/91, Gerardus Cornelis Ten Oever $v$ Stichting Bedrijfspensioenfonds voor het Glazenwassers- en Schoonmaakbedriff [1993] ECR I-4879. See, however. Case C-79/99, Julia Schnorbus v Land Hessen [2000] ECR I-10997, where the EC] qualifies the discrimination at hand of indirect and then regards it as being justified.

110 See, for example, Case 171/88. Ingrid Rinner-Kühn v FWW Spezial-Gebäudereinigung GmbH $\mathcal{E}$ Co. KG [1989] ECR 2743 at para. 12. Note that in Case C-476/99, H. Lommers and Minister van Landbouw, Natuurbeheer en Visserij [2002] ECR I-2891 at paras 37-9, the justification of a positive action measure in favour of women was reduced to a less incisive proportionality test.

111 Case 170/84, Bilka-Kaufhaus GmbH v Karin Weber von Hartz [1986] ECR 1607 at paras 36-7.

112 Case C-25/02, Katharina Rinke vÄrztekammer Hamburg [2003] ECR I-8349 at para. 39.

113 See Petrovic vaustria (2001) 33 EHRR 14 at para. 37; Abdulaziz, Cabales and Balkandali v United Kingdom A 94; (1985) 7 EHRR 471 at para. 78; Burghartz v Switzerland (1994) 18 EHRR 101 at para. 27.

114 See $L$ and $V$ v Austria (2003) 36 EHRR 55 at para. 45.

115 See, for example, Petrovic v Austria (2001) 33 EHRR 14 at para. 38. See also. Stec and others v United Kingdom (2005) 41 EHRR SE18 at paras 52 and 60-5. 
discrimination. The reasons provided need not be weightier or less weighty than in other cases. In view of the recent case law pertaining to age and disability under the Directive 2000/78/EC, ${ }^{116}$ however, age and disability discrimination seem to be submitted to a stronger proportionality requirement than other grounds of discrimination. This might indicate that the justifications required for gender-based discrimination are less stringent. The largely pragmatic and casuistic nature of the ECJ's approach in those matters, however, makes it difficult to draw any general rule as to the development of a differentiated regime of justification.

\section{Procedural Constitutive Elements}

The procedural dimension of the ECHR and EU anti-discrimination regimes reflect the fundamentally different role and approach of the two European Courts. There are three procedural elements that come out of both regimes and reflect those differences: evidence and burden of proof, level of scrutiny and margin of appreciation.

\section{(i) Evidence and burden of proof}

The issue of the evidence of discrimination amounts to the degree and the way in which the allegation, of an unjustified differential treatment of comparable cases on the grounds of sex, needs to be substantiated. Closely connected to this question, the issue of the burden of proof has been at the core of the development of gender discrimination law in Europe since the beginning, as applicants are often hindered by the difficulty there is to provide evidence of gender discrimination in certain cases.

The ECJ adopts a nuanced approach to evidence issues. In case of direct discrimination, the Court does not require evidence of a discriminatory intent. Evidence of an explicit discrimination is sufficient. In case of indirect discrimination, the ECJ was very innovative from the beginning. While it required that the likelihood of disadvantage for the applicant be proven in cases of discrimination based on nationality ${ }^{117}$ and, more recently, that at least the liability of disadvantage for a higher proportion of non-nationals be proven ${ }^{118}$, it has adopted a different approach in cases of indirect gender discrimination; there, what is required is evidence of impact on a substantially higher number of women or men. ${ }^{119}$ This may be provided by statistical evidence, on the model

116 See Case C-144/04, Werner Mangold v Rüdiger Helm [2005] ECR I-9981 at para. 65; Case C-13/ 05. Sonia Chacón Navas v Eurest Colectividades SA [2006] ECR I-6467; and Case C-303/06. S. Coleman v Attridge Law and Steve Law OJ 2008/C 223/08; [2008] ECR, unreported.

117 Case 152/73, Giovanni Maria Sotgiu v Deutsche Bundespost [1974] ECR 153 at paras 12-3.

118 Case C-237/94, John O'Flynn vadjudication Officer [1996] ECR I-2617 at paras 18-21.

119 Case 96/80, J.P. Jenkins v Kingsgate (Clothing Productions) Ltd [1981] ECR 911 at paras 11-15. 
of what applies to private discrimination prohibited by Title VII of the Civil Rights Act 1964 in the United States. ${ }^{120}$ It is unclear at the moment whether the slightly different wording chosen to define indirect discrimination in Directive 97/80/EC and the revised version of Article 2(2) Directive 76/207/EEC will have any impact on the kind of evidence to be produced. Whereas it is clear that the evidence of a substantially higher impact need no longer be brought, the applicant should provide evidence of the reality of the disadvantage and not only of its likelihood. ${ }^{121}$

Of course, the possibility of bringing statistical evidence of a considerable impact on those of one sex is not necessarily easy. ${ }^{1.22}$ To prevent evidence from becoming an insurmountable hurdle for discrimination victims, the ECJ quickly allowed the burden of proof to shift once a prima facie case of discrimination has been made. ${ }^{123}$ This practice relative to the evidence of indirect discrimination was codified in Article 4 of the Burden of Proof Directive 97/80/ EC, which has now become Article 19 Directive $2006 / 54 /$ EC. $^{124}$ In any case, it remains a matter for the relevant national body to appreciate the facts from which to presume that there is a case of direct or indirect discrimination. ${ }^{125}$

Under Article 14 ECHR, in contrast, the degree of evidence to be provided is high. In principle, the ECtHR requires evidence of the discriminatory intent. In certain exceptional cases, the Court is satisfied with mere evidence of explicit discrimination, but the case should be made beyond any reasonable doubt.' ${ }^{126}$ There are no accommodations made in the case of direct gender discrimination and the burden of proof does not shift to the State once the proof of the likelihood of discrimination has been provided. In principle, the same applies to the evidence of indirect discrimination. ${ }^{127}$ In a recent case, however,

120 See on the American notion of 'disparate impact', Griggs v Duke Power Co $401 \mathrm{US} 424,91 \mathrm{~S} \mathrm{Ct}$ 849 (1971) and Dothard $v$ Rawlinson 433 US 321, 97 S Ct 2720 (1977).

121 See, for a critique, Martin, supra n. 5 at 209-10.

122 See. for example. Case C-167/97. Regina $v$ Secretary of State for Employment, ex parte Nicole Seymour-Smith and Laura Perez [1999] ECR I-623 at para. 59.

123 See, for example, Case C-127/92, Dr. Pamela Mary Enderby v Frenchay Health Authority and Secretary of State for Health [1993] ECR I-5535 at paras 13-4; Case C-400/93, Specialarbejderforbundet i Danmark v Dansk Industri, formerly Industriens Arbejdsgivere, acting for Royal Copenhagen A/S [1995] ECR I-1275 at paras 24, 34 and 37.

124 Article 4(1) Directive 97/80/EC reads:

Member States shall take such measures as are necessary, in accordance with their national judicial systems, to ensure that, when persons who consider themselves wronged because the principle of equal treatment has not been applied to them establish, before a court or other competent authority, facts from which it may be presumed that there has been direct or indirect discrimination, it shall be for the respondent to prove that there has been no breach of the principle of equal treatment.' (emphasis added)

125 See Preamble to Directive 2006/54/EC, at para. 30.

126 See Velikova v Bulgaria 2000-VI at para. 94, and Hugh Jordan v United Kingdom (2003) 37 EHRR 2 at para. 154. See De Schutter, supra n. 5 at 16, and Martin, supra n. 5 at 251.

127 See Hugh Jordan v United Kingdom (2003) 37 EHRR 2 at para. 154. See De Schutter, supra n. 5 at 16. 
the European Court changed its practice following the ECJ's case law. Accordingly, the applicant only needs to prove 'the disproportionately prejudicial effect on a particular group. ${ }^{128}$ Evidence of such a disproportionately prejudicial effect may be provided by undisputed official statistical evidence, as confirmed in the Hoogendijk case. ${ }^{129}$ It is only once statistical evidence has been provided, however, that the burden of proof of objective justifications can shift to the State. The ECtHR has not yet organised a specific accommodation of the burden of proof in cases of direct gender discrimination based on the model of the EU burden of proof directive.

\section{(ii) Level of scrutiny}

Once a prima facie case of discrimination has been made by the applicant, the court needs to assess whether the differential treatment can be justified. The courts can apply different levels of scrutiny that will match the weight that the justifications should have and the degree of proportionality that should be respected.

The ECJ and the ECtHR diverge a lot on this subject. The ECtHR distinguishes, as we saw previously, between ordinary and suspect grounds of discrimination. Gender is classified among the latter and calls therefore for a heightened degree of scrutiny on the part of the Court. The Court requires 'very weighty reasons' for a differential treatment on grounds of sex to be justified and the proportionality test is also more demanding in such a case. ${ }^{130}$

The ECJ, in contrast, does not distinguish, in its case law, between different grounds of discrimination and applies prima facie the same level of scrutiny to cases of gender discrimination as to discrimination on any other ground. As discussed before, however, the ECJ's recent practice reveals variations between the tests used in cases of discrimination on grounds of nationality

128 See Hugh Jordan $v$ United Kingdom (2003) 37 EHRR 2 at para. 154. In the case of gender discrimination, see Hoogendijk v Netherlands (2005) 40 EHRR SE22 at 207.

129 Hoogendijk $v$ Netherlands (2005) 40 EHRR SE22, 207, where the Court said:

The Court considers that where an applicant is able to show. on the basis of undisputed official statistics, the existence of a prima facie indication that a specific rule - although formulated in a neutral manner - in fact affects a clearly higher percentage of women than men, it is for the respondent Government to show that this is the result of objective factors unrelated to any discrimination on grounds of sex. If the onus of demonstrating that a difference in impact for men and women is not in practice discriminatory does not shift to the respondent Government, it will be in practice extremely difficult for applicants to prove indirect discrimination.

On more recent use of statistical evidence to prove indirect discrimination, see Zarb Adami $v$ Malta (2006) 44 EHRR 3 at paras 78 and 82-3 (indirect sex discrimination) and D.H. and others v Czech Republic Application No. 57325/00. Judgment of 2007, at paras 179-80 and 187-95 (indirect race discrimination).

130 See Abdulaziz, Cabales and Balkandali v United Kingdom A 94 (1985); 19857 EHRR 471 at para. 78, and Burghartz $v$ Switzerland (1994) 18 EHRR 101 at para. 27. 
and sex discrimination. ${ }^{131}$ Moreover, the ECJ has applied a stricter test of proportionality in a recent case of age discrimination. ${ }^{132}$ In the Mangold case, the ECJ required that the alleged justification be individualised to be able to be regarded as such, whereas it has never required this level of individualisation in case of gender discrimination. ${ }^{133}$ The largely pragmatic and casuistic nature of the ECJ's approach in those matters, however, makes it difficult to draw any general conclusion as to the development of differentiated levels of scrutiny. ${ }^{134}$

\section{(iii) Margin of appreciation}

Because the two regimes compared are international regimes and the two jurisdictions in charge of interpreting them are supranational, the question of the margin of appreciation granted to the Member States of the EU and to the Contracting States of the ECHR is an important one.

In EU law, Member States' margin of appreciation is traditionally limited with respect to the interpretation of Community concepts and principles, and of their derogations. Interestingly, however, the ECJ has proved quite generous in granting Member States a margin of appreciation in the context of derogations from the non-discrimination principle on grounds of gender. These cases are those in which Member States invoke their exclusive competences or competences they share with the Community as in the context of social policy and contrasting social objectives. ${ }^{135}$ However, since the prohibition of gender discrimination constitutes a fundamental right and principle of EU law, the ECJ has also been quite adamant that Member States' and Community's contrary policies should not be invoked to render the principle meaningless. ${ }^{136}$

Under Article 14 ECHR, and many other rights in the Convention, the ECtHR recognises a broad margin of appreciation to the Convention's Contracting Parties. The explanation lies in the minimal and subsidiary nature of the Convention's guarantees and especially of the ECtHR's jurisdiction. ${ }^{137}$

131 Compare Case C-237/94, John O'Flynn vAdjudication Officer [1996] ECR I-2617 at paras 18-21 with Case 96/80. J.P. Jenkins v Kingsgate (Clothing Productions) Ltd [1981] ECR 911 at paras 11-5.

132 Case C-144/04, Werner Mangold v Rüdiger Helm [2005] ECR I-9981. See also, most recently in the case of disability, Case C-13/05, Sonia Chacón Navas v Eurest Colectividades SA [2006] ECR I-6467 and Case C-303/06, S. Coleman vAttridge Law and Steve Law OJ 2008/C 223/08; [2008] ECR, republished. See Martin, supra n. 13 at 129, and Martin, supra n. 101.

133 See Martin, supra n. 13 at 129.

134 See Anardottir, supra n. 19 at 52, and Martin, supra n. 13 at 131.

135 See, for example, Case 184/83, Ulrich Hofmann v Barmer Ersatzkasse [1984] ECR 3047 at para. 27, and Case C-226/91, Jan Molenbroek v Bestuur van de Sociale Verzekeringsbank [1992] ECR I-5943 at para. 13.

136 See Case C-25/02, Katharina Rinke vÄrztekammer Hamburg [2003] ECR I-8349 at para. 39, and Case C-77/02, Erika Steinicke v Bundesanstalt für Arbeit [2003] ECR I-9027 at paras 63-4. See Martin, supra n. 5 at $162-3$.

137 See Lambert, 'Marge Nationale d'Appréciation et Contrôle de Proportionnalitë', in Sudre (ed.), L'interprétation de la Convention Européenne des Droits de l'Homme (Bruxelles: Bruylant, 1998) at 63. See also, Wildhaber 'A Constitutional Future for the European Court of Human Rights', (2002) 23 Human Rights Law Journal 161. More generally on standards of review in the context 
In contrast to what is the case in the EU legal order, there have been no transfers of competence under the Convention and the ECtHR cannot use the ECJ's competence-based approach to the margin of appreciation. As a result, in the context of gender discrimination, the margin of appreciation often dilutes the special protection granted to sex qua suspect classification in the ECtHR's case law. ${ }^{138}$ One example is social policy, where the ECtHR, on the basis of the ECJ's case law, recognises that objectives in national social policy may justify differential treatment on grounds of sex. ${ }^{139}$

Of course, the scope of the margin of appreciation will vary according to the circumstances, the subject matter and its background; in this respect, one of the relevant factors may be the existence or non-existence of common ground between the laws of the Contracting Parties. ${ }^{140}$ The lack of a common ground among Contracting Parties arose in the Fretté case, where the Court had to decide on the French refusal to allow a single homosexual man to adopt a child. The Court used the lack of common ground to reject the application, but reassuringly stated that the 'margin of appreciation should not, however, be interpreted as granting the State arbitrary power, and the authorities' decision remains subject to review by the Court for conformity with the requirements of Article 14 of the Convention. ${ }^{\prime 41}$ This statement did not prevent the Court from dismissing the case, however. In effect, the Court has turned the margin of appreciation into a test of arbitrariness. This comes close to neutralizing and hence undermining the whole purpose of the heightened scrutiny applicable to suspect grounds of discrimination like gender. ${ }^{142}$

\section{E. Special Features}

The non-discrimination principle may protect against different kinds of discrimination that themselves concretise different dimensions of equality. Equality does not always require a symmetrical treatment of equal situations and asymmetrical equality, and hence discrimination can also be protected to take into account specifically female or male circumstances or objective occupational requirements. Further, equality may not only mean formal or legal equality,

of anti-discrimination law, see Heringa, 'Standards of Review for Discrimination', in Loenen and Rodriguez (eds), Non-Discrimination Law: Comparative Perspectives (The Hague: Martinus Nijhoff, 1999) 25.

138 See Petrovic vAustria (2001) 33, EHRR 14 at para. 38.

139 See Hoogendijk $v$ Netherlands (2005) 40 EHRR SE22; Stec and others $v$ United Kingdom (2005) 41 EHRR SE18 at para. 52; Walker v United Kingdom Application No. 37212/02, Judgment of 22 August 2006, at para. 33 and Van Raalte $v$ Netherlands (1997) 24 EHRR 503 at para. 42.

140 See ECtHR cases, Petrovic vAustria (2001) 33 EHRR 14 at para. 38, and Abdulaziz, Cabales and Balkandali v United Kingdom A94 (1985); (1985) 7 EHRR 471 at para. 78.

141 Fretté $v$ France (2004) 38 EHRR 21 at para. 41. On the same topic, however, see the most recent decision by the ECtHR in E. B. $v$ France Application No. 43546/02, Judgment of 2008.

142 For a discussion, see Callewaert, 'Quel Avenir pour la Marge d'Appréciation?', in Mahoney, Matscher, Petzold and Wildhaber (eds), Protection des Droits de l'Homme: La Perspective Européenne-Mélanges à la Mémoire de Rolv Ryssdal (Bruxelles: Carly Heymans Verlag, 2000) 147. 
but also material equality, i.e. equality in terms of results. Formal equality might therefore have to be violated to ensure material equality in certain cases.

\section{(i) Symmetrical and asymmetrical equality}

Equality is usually said to be symmetrical in the sense that people deemed to be in comparable situations should be treated in a comparable way and people in different situations in a different way. In certain rare cases, however, men and women might be in a comparable situation (e.g. in terms of professional qualifications), but that comparability can itself be limited in certain respects when special features or circumstances that apply only to men or only to women apply. This might be the case when pregnant women need special protection during pregnancy and shortly after giving birth and when they are treated differently from men accordingly, or when men are by virtue of their physical constitution more able to fit certain occupational requirements and are therefore treated differently from women.

In EU law, cases of asymmetrical equality are well-known and exceptionally justified despite the prima facie discrimination in favour of men or women and despite the violation of Article 2(1) Directive 76/207/EEC. Thus, Article 2(7) Directive 76/207/EEC calls for special protection of women in case of pregnancy. ${ }^{143}$ This approach to asymmetrical equality is reflected by the ECJ's case law on the protection of pregnant women discriminated at work. ${ }^{144}$ The Court is very strict, however, to prevent the need for special protection to turn into paternalism. In the Griesmar case, for instance, it distinguishes carefully between compensation for pregnancy and compensation for child care. ${ }^{145}$ Article 2(6) Directive 76/207/EEC allows, on the other hand, certain sex-based differentiations to be made by reference to genuine and determining occupational requirements. ${ }^{146}$ The ECJ has decided numerous cases on that basis in the

143 Article 2(7) Directive 76/207/EEC reads:

'This Directive shall be without prejudice to provisions concerning the protection of women, particularly as regards pregnancy and maternity' This article will eventually be replaced by Articles 15 and 16 Directive 2006/54/EC whose content is the same, but which delineate the circumstances of asymmetrical equality in more detail.

144 Compare Case C-177/88, Elisabeth Johanna Pacifica Dekker v Stichting Vormingscentrum voor Jong Volwassenen (VJV-Centrum) Plus [1990] ECR I-3941 with Case C-179/88, Handels- og Kontorfunktionaerernes Forbund i Danmark v Dansk Arbejdsgiverforening (Hertz) [1990] ECR I-3979. See also Case C-147/02. Michelle K. Alabaster $v$ Woolwich plc and Secretary of State for Social Security [2004] ECR I-3101 at para. 46.

145 Case C-366/99. Joseph Griesmar v Ministre de l'Économie, des Finances et de l'Industrie and Ministre de la Fonction publique, de la Réforme de l'État et de la Décentralisation [2001] ECR I-9383 at paras 39-46, 56. See also Case C-345/89, Criminal proceedings against Alfred Stoeckel [1991] ECR I-4047 at paras 14-18 on night work.

146 Article 2(6) Directive 76/207/EEC reads:

Member States may provide, as regards access to employment including the training leading thereto, that a difference of treatment which is based on a characteristic related 
military context in particular, where it only upheld the exclusion of women from certain military or police forces where there was a genuine and determining occupational requirement and the strictest proportionality test could be respected. ${ }^{147}$

Under Article 14 ECHR, equality seems to be largely understood in symmetrical terms. Certain decisions in the ECtHR's case law testify to an asymmetrical approach, however. This is the case, for instance, in the context of pregnancy and child-care ${ }^{148}$ or of military service. ${ }^{149}$ In this respect, one may notice a higher propensity for the Court to respect Contracting Parties' margin of appreciation when the applicants are men than women. ${ }^{150}$ As a result, the asymmetrical approach in the ECtHR's case law has a paternalistic and traditional flavour that is difficult to reconcile with the ECJ's decisions on similar issues. ${ }^{151}$

\section{(ii) Formal and material equality}

There can be cases where men and women are equally situated and where there are no specific features or circumstances that require an asymmetrical treatment, but where a formal discrimination is required to redress past material or formal discriminations and hence to ensure present material equality. Affirmative or positive action measures exemplify the requirements of material equality.

Until 1995, there was little discussion of material equality and affirmative or positive action in favour of women in EU law. ${ }^{152}$ Since the Kalanke case,

to sex shall not constitute discrimination where, by reason of the nature of the particular occupational activities concerned or of the context in which they are carried out, such a characteristic constitutes a genuine and determining occupational requirement, provided that the objective is legitimate and the requirement is proportionate.' This notion of occupational requirement is very similar to the American Civil Rights Act 1964's notion of 'bona-fide-occupational-qualification.

This provision will eventually be replaced by Article 14(2) Directive 2006/54/EC, which repeats its content.

147 Compare Case C-285/98. Tanja Kreil v Bundesrepublik Deutschland [2000] ECR I-69 at paras 20-9 with Case C-273/97, and Angela Maria Sirdar v The Army Board and Secretary of State for Defence [1999] ECR I-7403 at paras 23-31. Compare these cases with the second half of Dothard v Rawlinson 433 US 321, 97 S Ct 2720 (1977).

148 See Petrovic vAustria (2001) 33 EHRR 14.

149 Asnar v France Application No. 57030/00, Judgment of 17 June 2003.

150 See, for example, Petrovic v Austria (2001) 33 EHRR 14 at paras 42-3; Asnar $v$ France Application No. 57030/00, Judgment of 17 June 2003 at para. 28. Compare with Case C-79/ 99. Julia Schnorbus v Land Hessen [2000] ECR I-10997 at paras 40-7, that concerns compensation for past disadvantages imposed on men.

151 Compare, for example, Case C-366/99, Joseph Griesmar v Ministre de l'Économie, des Finances et de l'Industrie and Ministre de la Fonction publique, de la Réforme de l'État et de la Décentralisation [2001] ECR I-9383 with Petrovic vAustria (2001) 33 EHRR 14, or Case C-79/99, Julia Schnorbus v Land Hessen [2000] ECR I-10997 with Asnar v France Application No. 57030/00. Judgment of 17 June 2003.

152 Interestingly, Case C-450/93, Eckhard Kalanke v Freie Hansestadt Bremen [1995] ECR I-3051 was decided the same year as the US Supreme Court's decision in Adarand Constructors, Inc. $v$ Pena 515 US 200, 115 S Ct 2097 (1995) that announced the end of many state-run positive action programmes. See the comparison in Martin, supra n. 5 at 163-77, and Fredman. 'Reversing Discrimination', (1997) 113 Law Quarterly Review 575. 
however, and the other cases that followed, the issue has become central in EU gender discrimination law. In Kalanke, the Court adopted a rigid position against the protection of equality of results and positive measures that give absolute priority to women in case of under-representation, and justified its position by reference to the principle of equality of chances as protected by Article 2(4) Directive 76/207/EEC (in its old version). ${ }^{153}$ Following Germany's reaction and the controversy that raged shortly after the decision, the Court nuanced its position in the Marschall and Badeck cases where it accepted flexible quotas that give priority to women of equal competence albeit not in an absolute fashion, but under a saving clause that allows to take male candidates' specific circumstances into account. ${ }^{154}$ Since then. Article 141 was revised and paragraph 4 was added to it. In the same vein, Article 2(8) Directive 76/207/EEC was revised and Article 3 Directive 2006/54/EC was phrased on that basis. Finally, Article 7 Directive 2000/78/EC and Article 23(2) EU Charter of Fundamental Rights also mention the possibility for Member States to adopt positives measures to promote material equality.

When read strictly, Article 14 ECHR, at least in its French version, would seem to exclude material equality and positive action. It states that the rights in the Convention should be exercised without 'discrimination' (sans distinction aucune, in French). The ECtHR rapidly stated, however, that it should be understood broadly and encompass material as much as formal equality. ${ }^{155}$ One may not exclude therefore, although they have not been any cases so far, that a positive action scheme may be deemed as compatible with Article 14 ECHR.

\section{Proposals for Reform}

The ECHR and EU law have very different approaches to gender discrimination and these different approaches emerge clearly from the ECtHR's and the ECJ's case law. When both regimes apply to the same facts, contradictory solutions might therefore frequently arise. Recently, the two Courts have started a dialogue and mutual borrowing habits, but the latter have only been used

153 Case C-450/93, Eckhard Kalanke v Freie Hansestadt Bremen [1995] ECR I-3051 at paras 17-23.

154 Case C-409/95. Hellmut Marschall $v$ Land Nordrhein-Westfalen [1997] ECR I-6363 at paras 31-5, and Case C-158/97, Georg Badeck and Others, interveners: Hessische Ministerpräsident and Landesanwalt beim Staatsgerichtshof des Landes Hessen [2000] ECR I-1875 at paras 26-38. See also, most recently, Case C-407/98, Katarina Abrahamsson and Leif Anderson v Elisabet Fogelqvist [2000] ECR I-5539 and Case C-476/99. H. Lommers and Minister van Landbouw. Natuurbeheer en Visserij [2002] ECR I-2891.

155 Cases relating to certain aspects of the laws on the use of languages in education in Belgium A 6 (1968); (1979-80) 1 EHRR 252 at para. 10, where the Court said 'The competent national authorities are frequently confronted with situations and problems which, on account of differences inherent therein, call for different legal solutions: moreover, certain legal inequalities tend only to correct factual inequalities. The extensive interpretation mentioned above cannot consequently be accepted.' 
sporadically and strategically so far. ${ }^{156}$ Moreover, concrete borrowings have had no impact on the regimes themselves and have triggered no fundamental reorganisation of the respective regimes of non-discrimination. Whereas mutual borrowings of this kind might be recommendable from a short-term perspective, it presents the risk of producing incoherent decisions both synchronically within each legal order and diachronically within and among the two legal orders. ${ }^{157}$ Thus, while it is true that comparative constitutional law has crucial virtues in a pluralistic European legal order where convergence ought to take place gradually and be tested incrementally, ${ }^{158}$ it also has its downsides when the systems which are compared and whose solutions are mutually borrowed are not sufficiently close in their aims and structures.

A long-term solution requires a two-tiered reform, where both steps need to be taken in turn and in the proposed order to ease progressive convergence without undermining autonomy and diversity. A first step would be for each Court, helped by its legislature in the case of the EU, to start theorizing and systematizing its respective gender non-discrimination regime. Once categories have become clearer and the case law less fluctuating, comparative constitutional law and mutual borrowings of the kind that started in the past few years might become more fruitful. The real normative change, however, will only come in a second stage with the EU's accession to the ECHR. Following accession, the ECHR's catalogue will be vested with the constitutional rank it ought to have in a constitutionalised legal order like the EU's and the ECtHR will become the ultimate human rights court in Europe. From the perspective of gender discrimination, accession will provide victims of gender discrimination with a more coherent and hence more efficient answer, without, however, undermining the EU's idiosyncratic anti-discrimination measures and depriving European men and women from one of the most advanced antidiscrimination law regimes.

\section{A. Systematisation}

In view of the fundamental divergences between the two regimes, it is important that both Courts and the EU legislature start theorising and systematising the gender anti-discrimination regimes in those twin European post-national legal orders. EU law now owns a recast Directive 2006/54/EC in the field of gender discrimination that will replace all previous directives by 2009 and has codified much of the ECJ's case law. Nothing signals, however, that the ECJ's case law will become less fluctuating, although it is important that it

156 See also, Martin, supra n. 5 at $132-4$.

157 On synchronic and diachronic coherence, see Besson. The Morality of Conflict. Reasonable Disagreement and the Law (Oxford: Hart Publishing, 2005) Ch. 8.

158 See, for example, Douglas-Scott, supra n. 6, and Besson, supra n. 14. 
defines clearly the material and procedural constitutive elements of the prohibition of gender discrimination and abides by those definitions. In the ECHR gender discrimination regime, on the other hand, change might stem from Protocol 12 if it is more broadly ratified, since it provides the ECHR with an independent and general equal protection clause. As of late, signs of a corresponding strengthening and systematisation of the ECtHR's approach in its case law are perceptible.

To start with, it is essential that both legal orders clarify and strengthen the relationship between the prohibition of gender discrimination and the principle of equality in general. The future constitutionalisation of the principle of equality in EU law and the progressive ratification of Protocol 12 among Contracting Parties to the ECHR confirm the need to tie gender discrimination more closely to the general principle of equality to ensure more coherence in each regime and the legal reasoning applicable. More specifically, this will ensure that EU gender discrimination law develops a coherent personal and material scope and be vested with a more systematic impact on national law without depending on the specific sources of the principle of nondiscrimination in each case.

Furthermore, it is important that gender be given a heightened protection in EU law. The ECJ's pragmatic approach has been largely beneficial in developing tailor-made solutions for gender qua ground of discrimination. This was exemplified in the context of the justification of indirect gender discrimination and by the alleviation of the burden of proof. However, based on Directive 2000/ $78 / \mathrm{EC}$ and the development of other prohibited grounds of discrimination in EU law, the ECJ's casuistic approach has led to increasing incoherence between the regimes applicable to different grounds of discrimination and paradoxically to the development of a hierarchy of grounds and corresponding scrutiny where gender is no longer ranked as high as it ought to be. Evidence of the high-rank gender deserves in the hierarchy of grounds of discrimination in EU law may be found in its central place in the EC Treaty since 1957, the development of secondary law since 1975 culminating in the 2004/113 and 2006/54 Directives, the place of gender equality among the EU's goals in Articles 2 and $3 \mathrm{EC}$ and Article 23 EU Charter. The ECJ could benefit in this respect from the ECtHR's own classifications and experience with heightened scrutiny in the legal reasoning applicable to sex discrimination. In this respect, it is important that the ECtHR abides more systematically by the higher rank of gender qua suspect ground of classification in its own case law. For instance, it should prevent the erosion of heightened scrutiny in this context, by relinquishing its overbroad use of the margin of appreciation when arguments of social policy are made or when male applicants are concerned.

Another dimension where ECHR and EU gender discrimination law needs to be reformed is the distinction between direct and indirect discrimination. 
By fine-tuning its understanding of differential treatment, the ECtHR would be able to raise the level of protection of men and women who are discriminated in covert ways by prima facie neutral requirements. In this respect, the ECtHR has already started benefiting in its most recent case law from the ECJ's nuanced distinctions and definitions. ${ }^{159}$ The ECJ itself needs, however, to clarify the ambiguity among the various definitions of indirect discrimination used in the latest European directives. Further systematisation is also needed with respect to the conditions for the justification of direct and indirect discriminations. The differences between the two types of discrimination need to be reflected in the kinds of justification that can be accepted in contrast to the ECtHR's case law. The ECJ's practice can constitute an important source of inspiration in this respect, although the ECJ needs to clarify whether or not and why direct discrimination may be justified. After all, direct discrimination based on other grounds than gender is justifiable in EU law and so is direct gender discrimination under ECHR law.

A final dimension of both European regimes that needs to be systematised is evidence and the organisation of the burden of proof. While evidence and alleviating the burden of proof has been at the centre of the ECJ's case law in gender discrimination for years, a similar evolution has only just started under ECHR law. It is important that sex discrimination receives adequate procedural treatment in this respect in the ECtHR's case law. The requirement of evidence of discriminatory intent is entirely inadequate in circumstances of indirect discrimination and, even in cases of direct discrimination, the absence of ways to shift the burden of proof constitutes a severe hindrance for discriminated applicants. ${ }^{160}$

Once those different elements are addressed more openly and consistently within each Court's case law, it is likely that their case law will offer more ready solutions for them to borrow from each other. As a result, comparative constitutional law will be able to contribute to the soft kind of harmonisation one may hope for in the human rights context in Europe. When the two systems compared are sufficiently systematised and judges aware of their similarities and differences, comparisons and free mutual borrowings in specific cases constitute one of the least sovereignty-offending means of convergence in a pluralistic European legal order lato sensu. ${ }^{161}$

159 See, for example, Zarb Adami v Malta (2006) 44 EHRR 3 at paras 78 and 82-3.

160 See, however, Zarb Adami v Malta (2006) 44 EHRR 3 at paras 78, and 82-3 (indirect sex discrimination) and D.H. and others v Czech Republic Application No. 57325/00, Judgment of 2007 (indirect race discrimination).

161 See Besson, supra n. 14 and Besson, 'Sovereignty in Conflict', in Tierney and Warbrick (eds), Towards an International Legal Community. The Sovereignty of States and the Sovereignty of International Law (London: BIICL, 2006) 131. 


\section{B. Accession}

Since the 1960s, human rights have triggered constitutionalisation of the European legal order qua constraint on European power. Recently, however, they have also turned into an irresistible albeit controversial force of constitutionalisation qua normative empowerment of European institutions. Scope precludes going into the details of the European constitutionalisation process in this article. ${ }^{162}$ At a time when human rights are constitutionalised via the EU Charter, however, it is becoming crucial for the EU to ratify the ECHR and hence submit itself to the same human rights catalogue as its Member States. $^{163}$ New Article 6(2) EU, as amended by the 2007 Lisbon Treaty, attests of the political will in favour of accession in the EU. ${ }^{164}$ Moreover, recent signals on the part of the Council of Europe attest to the reciprocal interest in the EU joining the Convention following Protocol 14's amendment of the personal conditions of accession. ${ }^{165}$

In the context of gender discrimination, accession would provide a minimal threshold in terms of anti-discrimination protection in the EU and the submission of European authorities to binding albeit subsidiary decisions of the ECtHR in discrimination cases. Despite its opponents' fear, accession can be said to offer the best of both worlds. Security and coherence should not indeed come at the price of protection and sovereignty. Two main sets of arguments explain how this is possible.

On the one hand, there would be no risk of levelling-down following accession or even of denaturing the EU's more advanced gender discrimination regime. $^{166}$ The ECHR is conceived as a minimal and subsidiary catalogue of human rights. Thus, Article 53 ECHR read together with Article 52(3) EU Charter enables not only Member States but also the EU to develop higher protection mechanisms against gender discrimination. Moreover, the ECtHR's protection of the Contracting Parties' margin of appreciation that is used to accommodate Contracting Parties' social goals and policies could extend to the EU's social goals and protect its more advanced anti-discrimination

162 See, for example, Maduro, 'The Importance of Being Called a Constitution: Constitutional Authority and the Authority of Constitutionalism', (2005) 3 International Journal of Constitutional Law 332.

163 See relative to arguments relative to accession and its modalities, McCrudden, "The Future of the EU Charter of Fundamental Rights', Jean Monnet Working Paper 10/2001, and Dutheil de la Rochère, 'Droits de l'Homme: La Charte des Droits Fondamentaux et Au-delà', Jean Monnet Working Paper 10/2001.

164 See, for example, Douglas-Scott, supra n. 6.

165 See Junker, "Conseil de l'Europe - Union Européenne: "Une Même Ambition pour le Continent Européen"', 11 April 2006, available at: http://assembly.coe.int/Sessions/2006/speeches/ 20060411_rapportJCJunckerFR.pdf [last accessed 19 June 2008].

166 Contra Martin, supra n. 13 at 133, whose view of the impact of the ECHR and the ECtHR's judgments on EU (and national) law seems to reflect that of EU law on national law, whereas its immediate validity, primacy and applicability abide by a different and more subsidiary international model where hierarchy is no longer the key concern. See Besson, supra n. 16. 
policies. In fact, it follows from the review of cases presented earlier that no Contracting Party to the ECHR has ever had to lower its level of social protection against gender discrimination as a result of the ECtHR's case law, quite the reverse. Of course, the ways in which the ECtHR would be arbitrating the EU's and its Member States' policies and norms when they conflict with each other in a given case of gender discrimination remain to be seen. Given the presumption of Convention-compliance that applies since 2005 to EU law and decisions, ${ }^{167}$ however, the ECtHR is likely to grant the EU's margin of appreciation higher protection. Finally, the benefits of systematisation and mutual borrowings between the two Courts discussed previously will gradually contribute to reducing the possibility of a levelling-down of EU guarantees. It is likely indeed that the ECtHR will strengthen its approach to gender discrimination on the basis of the ECJ's case law and Protocol 12. This could be the case in particular relative to the level of scrutiny and burden of proof of indirect discrimination.

At the same time, the fear of seeing all ECJ's judgements relative to gender discrimination being superseded by those of the ECtHR is unfounded. The latter's jurisdiction would remain subsidiary and would require exhausting local remedies in EU Member States, but also probably in Luxembourg. In fact, a preliminary ruling system might help reduce the amount of cases triggering adverse judgments by the ECtHR; it would give the ECJ a chance to scrutinise its case law, while also allowing the ECtHR to strengthen its own gender discrimination case law in conceptual terms. This is after all what took place in the EU with the mutually reinforcing exchanges between the ECJ and national courts in the framework of preliminary rulings. ${ }^{168}$ Of course, the risk of overburdening the ECtHR should not be underestimated and needs to be factored into the current reform of the human rights monitoring system in the Council of Europe. ${ }^{169}$

\section{Conclusion}

From a comparative constitutional perspective, the sheer multiplicity of sources, scopes and contents of the guarantees of the non-discrimination principle in Europe is bewildering. Legal responses to gender discrimination are just as diverse in their sources, scope and content. The regimes of

167 See Case C-84/95, Bosphorus Hava Yollari Turizm ve Ticaret AS v Minister for Transport. Energy and Communications and others [1996] ECR I-3953.

168 See the essays in Slaughter, Stone Sweet and Weiler (eds), The European Court and the National Courts (Oxford: Hart Publishing, 1998).

169 Report of the Group of Wise Persons to the Committee of Ministers, 15 November 2006, CM(2006) 203. 
non-discrimination on grounds of sex in Europe, and most particularly under Article 14 ECHR and EU primary and secondary law, mirror 50 years of intense economic development in Europe but also of steady social progress, albeit seen through different lenses. As in so many other fields, the two European Courts sing the same song, but in two different and sometimes dissonant voices.

This article has tried to identify the main components of the two European gender discrimination regimes and capture their fundamental aims. Based on the divergences observed, it has made two suggestions as to how to allow more convergence without threatening the benefits of autonomy and diversity in human rights protection in Europe. These proposals should hopefully contribute to cultivating the two legal orders' common history and ensuring European legal security, without, however, betraying their respective specificities and complementarity in a complex Europe. Never shall the twain meet. 